\title{
The Internationalization of the Academic Library: A Systematic Review of 25 Years of Literature on International Students
}

\author{
Amanda B. Click, Claire Walker Wiley, and Meggan \\ Houlihan*
}

This study is a systematic review of the library and information science (LIS) literature related to international students and academic libraries. A systematic review involves the methodical collection and analysis of a body of literature and is growing in popularity in the LIS field. Three wellknown LIS databases were systematically searched for articles related to the topic, and manual bibliography searches were conducted to find additional publications. Journal articles, book chapters, and conference papers were included or excluded based on established criteria. Findings show that articles published about international students and academic libraries have increased steadily between 1990 and 2014. The majority of authors are affiliated with universities and institutions in the United States, although an increase in represented countries is apparent. Fewer than half of the articles can be considered original research, and surveys are the most popular method for data collection. The LIS field-and international students-would benefit from further exploration of this topic, particularly from original research with practical implications.

\section{Introduction}

The literature about issues related to international students in academic libraries is not as prevalent in the library and information science (LIS) literature as might be expected, particularly since the number of international students studying in the United States increased by 72 percent between the 1999-2000 and 2013-2014 academic years. ${ }^{1}$ However, because this student group may have unique research and information-seeking needs, a subsection of the literature does address various issues, support, and services for this population. The research presented here, a systematic review of this literature, seeks to explore who is studying international students, which methods are being used to do so, and which topics are of particular interest to the researchers. Petticrew and Roberts advocate for the use of the systematic review in this type of research, stating

*Amanda B. Click is the Business Librarian at American University, amanda.click@gmail.com; Claire Walker Wiley is a Research and Instruction Librarian at Belmont University; e-mail: claire.wiley@belmont. edu. Meggan Houlihan is a First-Year Experience and Instruction Librarian at New York University Abu Dhabi; e-mail: meggan.houlihan@nyu.edu. (C2017 Amanda B. Click, Claire Walker Wiley, and Meggan Houlihan, Attribution-NonCommercial (http://creativecommons.org/licenses/by-nc/4.0/) CC BY-NC. 
that this method can "provide a means of dealing with the information mountain, by allowing large amount of research information to be distilled into a manageable form." 2 To our knowledge, a systematic review of the literature regarding international students in academic libraries has not been previously conducted. The study was designed to synthesize the findings of a number of publications, provide information for practitioners wishing to better serve this population, and identify additional areas of study for the future.

The study detailed here adhered to Kelly and Sugimoto's steps for conducting a systematic review. ${ }^{3}$ Literature published between 1990 and 2014 was examined to identify and analyze the research about international students in academic libraries during the last 25 years. While the systematic review is not an often-used method in LIS research, it is gaining popularity and acknowledged as a valuable method. ${ }^{4} \mathrm{~A}$ recent publication from the Association of College \& Research Libraries (ACRL) cites systematic literature reviews as a method of which librarians should be aware for their own research and practice as well as to support the evidence-based practice of other researchers. ${ }^{5}$ The authors advocate for this and other evidence-based methods that can produce high-quality and implementable LIS research.

\section{Research Questions}

This study addresses the following research questions:

- Which trends in authorship can be identified in the LIS literature regarding international students?

- Which specific topics related to international students are addressed in the literature?

- Which research methods are commonly found in the LIS literature on international students?

\section{Literature Review}

The literature on international students in the academic library is a subset of the literature on the internationalization of the academic library, which can be considered an aspect of the internationalization of higher education. This review of the literature provides context by focusing on these larger themes. It includes definitions of important concepts and information about how internationalization in higher education has evolved over the years. It also covers perspectives on the internationalization of the academic library, including the literature on services for study-abroad students, the internationalization of library and information science (LIS) education, and the development of international branch campuses.

\section{Internationalization of Higher Education}

In her 2013 book, Internationalization and the North American University Library, Bordonaro points out that there is "not a single universally accepted definition of internationalization in higher education." ${ }^{6}$ More than 20 years ago, Knight offered the following: "Internationalisation of higher education is the process of integrating an international/ intercultural dimension into the teaching, research, and service functions of the institutions." 7 In 2004, she proposed a new working definition: "Internationalization at the national, sector, and institutional levels is defined as the process of integrating an international, intercultural, or global dimension into the purpose, functions or delivery of postsecondary education." ${ }^{\prime 8}$ This definition is still commonly used in the literature. Note that globalization and internationalization, while related, are not synonyms. According to Altbach and Knight, globalization refers to "the economic, political and societal forces pushing 21st-century higher education toward greater international 
involvement." 9 Thus, globalization is considered the underlying force for change, while internationalization is the process of change.

Clearly there has been interest in-and concern about-the internationalization of higher education for decades. In 1995, the American Council on Education (ACE) published Educating Americans for a World in Flux, which called for "major changes in how colleges and universities educate their students about the rest of the world." ${ }^{10}$ The document offered ten ground rules for the internationalization of higher education:

1. Require that all graduates demonstrate competence in at least one foreign language.

2. Encourage understanding of at least one other culture.

3. Increase understanding of global systems.

4. Revamp curricula to reflect the need for international understanding.

5. Expand study-abroad and internship opportunities for all students.

6. Focus on faculty developments and rewards.

7. Examine the organizational needs of international education.

8. Build consortia to enhance capabilities.

9. Cooperate with institutions in other countries.

10. Work with local schools and communities.

More recent literature calls for institutions of higher education to cultivate global competence, "the ability of faculty, staff and students to not only contribute to knowledge, but also to comprehend, analyze, and evaluate its meaning in the context of an increasingly globalized world." 11 These ideas are not only embraced by those in higher education. A 2004 report published by the Committee for Economic Development reiterated several of the ACE's "ground rules," stressing the importance of foreign language requirements, study abroad, international student recruitment, and international studies curricula. ${ }^{12}$

In 2012, ACE published the findings of the Mapping Internationalization on U.S. Campuses Survey, "which is designed to assess the current state of internationalization at U.S. institutions, examine progress and trends over time, and identify priorities going forward." ${ }^{13}$ Responding institutions indicated that internationalization has increased in recent years, with particular emphasis on curriculum development, overseas partnerships, and the recruitment of international students and faculty. The results of a related study focused on contributions by academic libraries to internationalization on U.S. campuses is briefly discussed in the next section.

\section{Internationalization of the Academic Library}

Witt, Kutner, and Cooper point out that the goal of the ACE survey is to provide a comprehensive overview of internationalization in U.S. higher education, but it does not include academic libraries. Modeling the survey, they conducted a study to explore the role academic libraries play in internationalization. Similar to the ACE study, findings showed increased internationalization activity and funding and also highlighted the importance of support from high-level leaders in the organization. However, the respondents to the ACE study tended to rate internationalization as "high" or "moderate" on their campuses, while the academic library respondents were much less likely to report at this level. The authors note that, "although internationalization activity has increased in responding libraries, explicit articulation of it in planning documents often has not occurred."14 Bordonaro also explored the role of university libraries in internationalization in a phenomenological study in which she surveyed librarians as well as international students and scholars in North America. Eighty-six percent of librarian respondents clearly believe that the library should play a role in internationalization. While they acknowledged the challenges of serving international 
populations, they identified many benefits: expanding the knowledge of librarians, providing personal satisfaction, improving library services, enriching campuses, and supporting the international flow of scholarly information. ${ }^{15}$

Much of the literature on the internationalization of the academic library is focused on serving international students. This subset will not be discussed in this review of the literature, as it will be thoroughly covered in the Findings and Discussion sections. Supporting study-abroad students is another evident theme. Wang and Tremblay describe the experience of providing library services and resources to students studying at their university's international centers in Costa Rica, China, India, Japan, and South Africa. After surveying students and faculty in the program, librarians were better equipped to develop and promote appropriate services like reference chat, electronic resources, and online tutorials. ${ }^{16}$ Denda collected data from students, administrators, and faculty in the study-abroad programs at her university and also conducted an environmental scan of library websites to collect information about services for studyabroad students. Her efforts resulted in new outreach initiatives such as a dedicated study-abroad research guide and library participation in events like the study-abroad outbound orientation. ${ }^{17}$ As a result of surveying study-abroad students in Costa Rica, Kutner discovered that these students were uncertain about remote access to library resources and services. For example, they were not confident in their abilities to access library databases or request interlibrary loan materials while abroad. Participants made a variety of suggestions for remedying this situation, including specialized library instruction and collaboration between the study-abroad office and library. ${ }^{18}$

The librarians who are responsible for the internationalization of the academic library are generally the products of LIS education. Abdullahi, Kajberg, and Virkus argue that international and intercultural perspectives and opportunities are a crucial part of training high-quality library and information professionals. They focus on curricular issues, such as revising existing curricula to integrate international issues, and developing an "internationally recognized professional qualification." 19 While this article focused on North America, Kajberg surveyed European LIS schools regarding internationalization activities. He found that half of the responding programs featured internationalization in their mission statements, and almost all specified that efforts have been made to internationalize the curriculum. A variety of examples were provided, including teaching some courses in English and developing reading lists with global perspectives. However, Kajberg does express some concern about the lack of "long-term, resource demanding, challenging collaborative initiatives and activities." ${ }^{20}$

Despite the growth of international branch campuses in recent decades, the literature on their academic libraries remains sparse. Related publications tend to be reflective pieces about the experiences of librarians abroad. ${ }^{21}$ In 2013, Green published the results of a survey of branch campus librarians, designed to learn more about the services offered by these libraries. While branch campus library outcomes were similar to those of U.S.-based libraries (such as helping students develop information literacy skills), some distinctive issues emerged from the data. The librarians at these campuses deal with unique challenges, often related to living and working in an unfamiliar culture. In addition, to provide services and resources to their patrons, they must negotiate collaborations with home institutions thousands of miles away. ${ }^{22}$ In a forthcoming book chapter, Click and Houlihan present findings of an exploratory study about information literacy and library instruction programs at American-style international libraries, including both branch campuses and autonomous institutions. Survey responses made it clear that most of the libraries use American standards for their library instruction programs, such as the ACRL Information Literacy Competency Standards for Higher Education, but adapt them to meet the needs of their student populations. ${ }^{23}$ 


\section{Method}

Petticrew and Roberts define systematic reviews as "literature reviews that adhere closely to a set of scientific methods that explicitly aim to limit systematic error (bias), mainly by attempting to identify, appraise and synthesize all relevant studies (of whatever design) in order to answer a particular question (or set of questions)." ${ }^{24}$ The systematic review is similar to content analysis. However, the former is focused on the analysis of research, while the latter emphasizes summarizing content. ${ }^{25}$ The systematic review is not especially common in the LIS field, although the literature indicates that it is slowly growing in popularity. Koufogiannakis, a proponent of evidence-based practice and systematic reviews, maintains a wiki that tracks systematic reviews in the LIS literature (http://lis-systematic-reviews.wikispaces.com/). In 2012, the wiki listed 37 articles total, 24 of which were in the health sciences librarianship subfield. ${ }^{26}$ By 2015 , the number of articles listed on the wiki had more than doubled to $82 .{ }^{27}$

This study uses a systematic review of the LIS literature to explore how modern academic libraries provide services and support to international students, answering research questions related to study design, authorship patterns, and research topics. Petticrew and Roberts recommend the use of systematic review under several circumstances, including:

- When a general overall picture of the evidence in a topic area is needed to direct future research efforts

- When an accurate picture of past research and past methodological research is required to promote the development of new methodologies. ${ }^{28}$

This study included the following steps:

1. Identify sources from which studies would be selected.

2. Develop and evaluate inclusion and exclusion criteria to guide the selection of articles from these sources.

3. Validate manual search and selection processes.

4. Develop a coding scheme for analyzing articles.

5. Apply coding scheme to articles. ${ }^{29}$

Each of these steps is explained further in the following subsections.

\section{Source Identification}

Because this study focused on academic libraries, we determined that the major LIS databases would be the best sources for literature on services for international students. We chose to search Library \& Information Science Source (LISS), Library and Information Science Abstracts (LISA), and Library, Information Science \& Technology Abstracts (LISTA). Once articles from these databases were collected, we performed a manual bibliography search of each to identify additional sources that fit our criteria but were not retrieved in the database searches. This technique resulted in the discovery and analysis of book chapters and conference papers in addition to journal articles.

\section{Inclusion and Exclusion Criteria}

This systematic review was designed to include all the scholarly LIS literature on international students in academic libraries, including journal articles, conference papers, books, and book chapters, published between January of 1990 and December of 2014. Often the LIS literature describes particular projects developed and undertaken in specific libraries. These publications generally would not be considered original research, and we will label these "what we did" pieces. Although they are not original research, they do provide information that helps to answer the research question and thus were included in the study. Book reviews and news articles were excluded, as well as dissertations and theses. All English-language articles, book chapters, books, 
and conference papers about international students in academic libraries found in the LISS, LISA, and LISTA databases or in the manual bibliography search were included in this review of the literature.

\section{Search and Selection Process}

We searched each of the three databases for articles with "international student" or "foreign student" in the title, abstract, subject terms, or author-supplied keywords. The results were filtered to include only results from peer-reviewed, scholarly journals. Initially, there were 161 results from LISS, 106 from LISA, and 143 from LISTA. After removing duplicates, we were left with a list of 121 articles to analyze. In this first round, we limited the search to articles published between 2000 and 2014. Upon expanding the scope of the study to 1990 to 2014, we conducted another database search and the manual bibliography searches. This expansion resulted in 110 additional publications, for a total of 231 to be analyzed.

\section{Code Development and Application}

Features of the articles, including those related to authorship, study design, and research topic, were manually coded. More detail about these features can be found in table 1 .

Some codes were developed prior to analysis, such as those for affiliation type, position category, method, and population type. Codes for these features were added and changed throughout the first round of coding. The category codes for topics were allowed to emerge from the data, but they were also finalized after the first round. Many of the publications were not original research, and, in most cases, study design features were not coded for these. Publications that included a methods or methodology section were identified as original research.

\begin{tabular}{|c|c|}
\hline \multicolumn{2}{|r|}{$\begin{array}{c}\text { TABLE } 1 \\
\text { Article Feature Types and Items }\end{array}$} \\
\hline Feature Type & Item \\
\hline \multirow[t]{3}{*}{ Publication } & Category (such as journal article, or book chapter) \\
\hline & Date \\
\hline & Research Classification (such as original research or general literature) \\
\hline \multirow[t]{5}{*}{ Authorship } & Name \\
\hline & $\begin{array}{l}\text { Affiliation Type (such as college or university library, LIS department, or } \\
\text { school) }\end{array}$ \\
\hline & Position Category (such as LIS faculty, librarian, $\mathrm{PhD}$ student) \\
\hline & Location by Country \\
\hline & Collaboration (such as single author, within library, between institutions) \\
\hline \multirow[t]{5}{*}{ Study Design } & Study Location by Country \\
\hline & Method (such as survey, interviews, pre- and post-tests) \\
\hline & $\begin{array}{l}\text { Population Type (such as undergraduate students, } \mathrm{PhD} \text { students, } \\
\text { librarians) }\end{array}$ \\
\hline & Population Country of Origin \\
\hline & $\begin{array}{l}\text { Theory and/or Models (such as Bruce's relational model of information } \\
\text { literacy, second language acquisition theories) }\end{array}$ \\
\hline Article Content & $\begin{array}{l}\text { Topics (such as reference services, multicultural/intercultural issues, } \\
\text { library instruction) }\end{array}$ \\
\hline
\end{tabular}


The 231 articles were divided into three sections, and two of the three authors analyzed each section. Following analysis, each set of authors discussed the coding of the shared one-third (77 articles) to ensure agreement. Thus, each author coded twothirds of the total articles. An additional 84 publications were excluded during this analysis, resulting in a total of 147 included in the study. Publications were removed for a variety of reasons. Many were not actually about international students; for example, participants were identified as "ESL," "multicultural," or "nontraditional." Others were not related to academic libraries. In addition, the manual bibliography search turned up many articles from nonscholarly publications, which were outside the scope of this systematic review. A list of all 147 journal articles, book chapters, and conference papers can be found in appendix A. Codes were finalized after this round. Finally, each author conducted a second round of coding, in which she analyzed the one-third of the articles she had not previously examined. At the end of this process, each article had been coded and agreed upon by all three authors. The final 147 articles were coded and analyzed in spreadsheet format. The study findings are shared using descriptive statistics, so more complex data analysis software was not necessary.

\section{Findings}

This section covers findings related to publication category (such as journal article or book chapter), authorship and collaboration, research methods, theories and topics, and study locations and populations.

\section{Publication Categories}

Of the 147 publications that met the study criteria, 117 were published in scholarly journals. Fifty-eight different journals were represented. Only six journals published five or more articles that met the study criteria: Reference Services Review (13), The Journal of Academic Librarianship (11), The Reference Librarian (10), The International Information $\mathcal{E}$ Library Review (6), Research Strategies (5), and College $\mathcal{E}$ Research Libraries (5). A list of all journals and the number of included articles for each can be found in appendix B. Twenty-one of the publications were book chapters. One book, Jackson and Sullivan's International Students and Academic Libraries: Initiatives for Success, contributed 13 of these chapters. ${ }^{30}$ Each was coded separately because this is an edited volume of chapters written by different authors. Thus, chapters from a total of nine books were included in the study. A handful of conference papers turned up in the search, mostly from conferences in Australia. Of the nine papers, only four were from LIS-specific conferences (such as the Australian Library and Information Association's Biennial Conference), and others were focused on other subfields in higher education (such as the Pacific Rim Conference on the First Year in Higher Education). All conference papers were published online or in print proceedings. Full citations for all journal articles, book chapters, and conference papers can be found in appendix A.

It should be noted that we found three annotated bibliographies that would be of value to anyone in the LIS field interested in this topic but were not included in the study. We searched them for relevant publications, but did not include them in the analysis because our coding scheme was not designed for this type of publication. They are listed in appendix C. Note that the Moeckel and Presnell bibliography is actually a companion piece to an article that is included in the study. ${ }^{31}$

The trend line in figure 1 shows that the number of publications increased steadily over this 25-year period. This study identified only one publication about international students and academic libraries in both 1996 and 1999. The high in 2011 (18 publications) can be attributed to the 13 chapters in International Students and Academic Libraries: Initiatives for Success. 


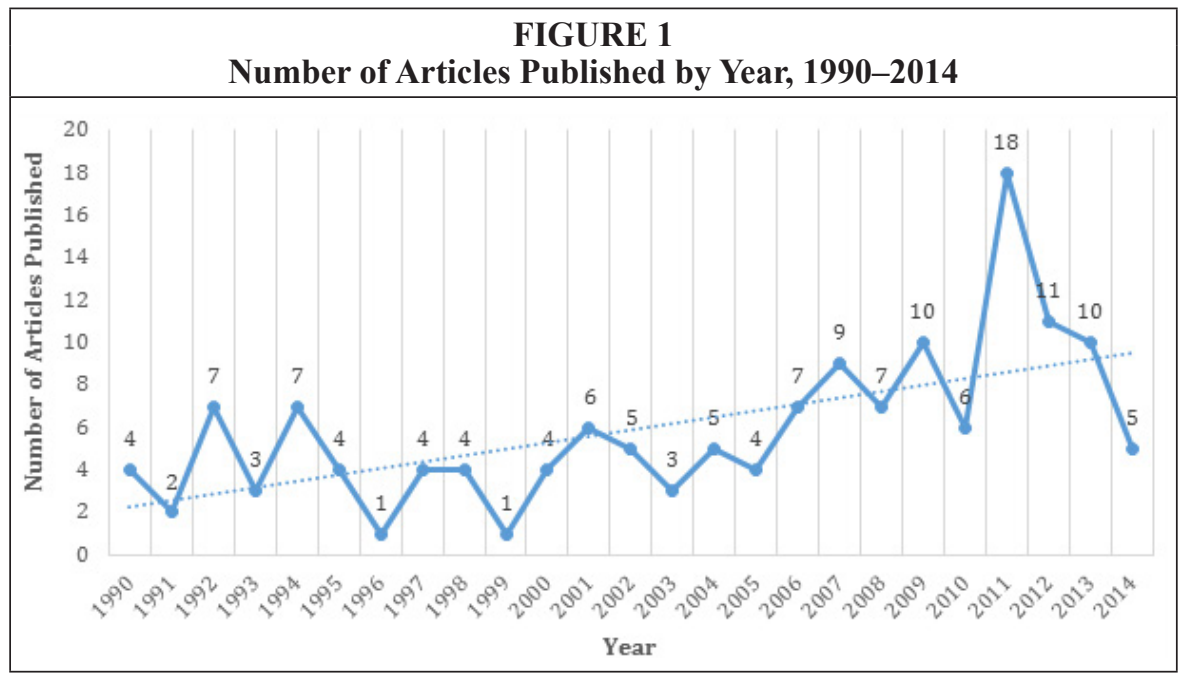

\section{Authorship and Collaboration}

For the 147 articles included in the systematic review, there were a total of 239 authors. Specific job titles were unknown for half of the authors. Of those whose positions were clearly listed, 91 (38\%) identified as a librarian and $9(4 \%)$ as LIS faculty. A few faculty from other, and sometimes unexpected, disciplines including business information, education, math, and marketing also contributed to the literature. Only six authors were identified as PhD students. More than half of the author titles were unknown, due to lack of information and consistency in how journals describe authors of articles. Many articles listed only faculty rank, such as assistant professor, or only

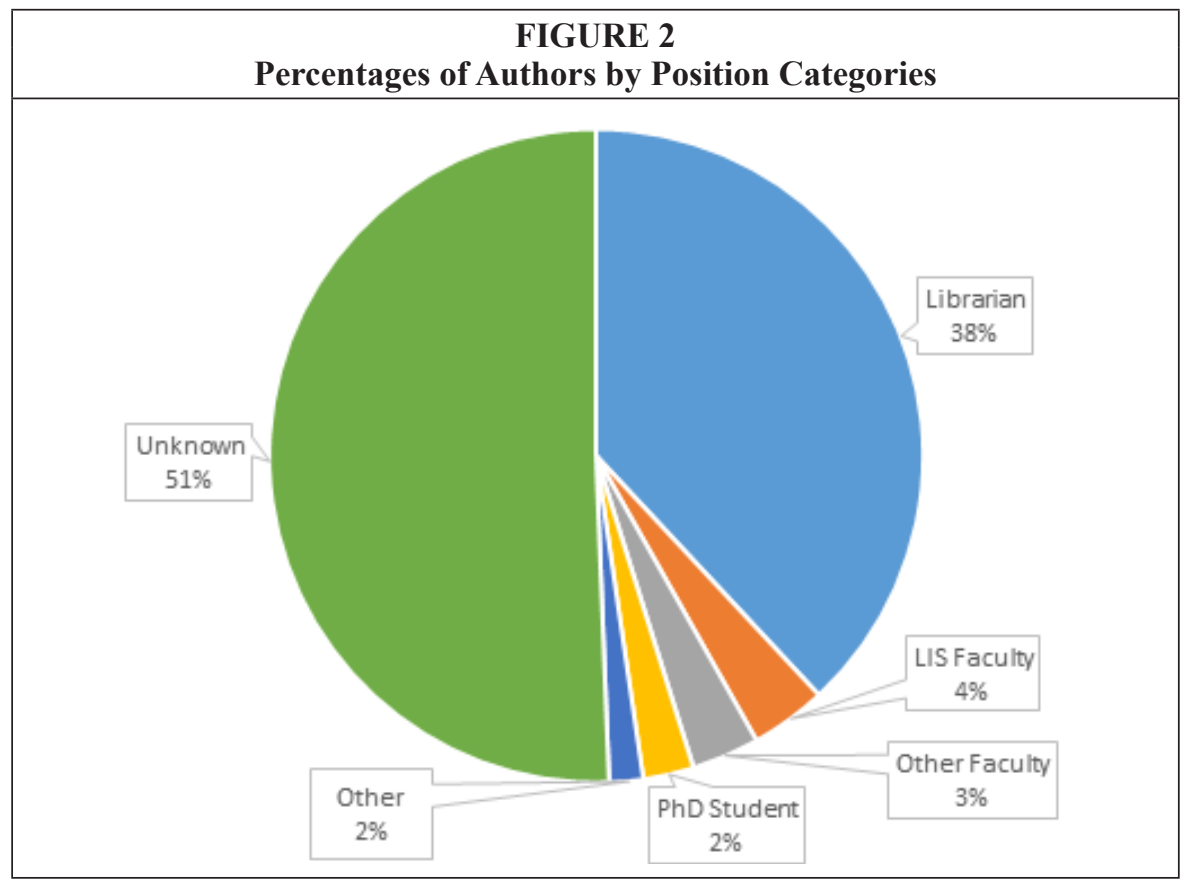


included the name of the university. An author was only classified as "librarian" if a specific job title was listed either in the byline or author notes, whether or not the article text made it clear that the author was a librarian. Author position categories are summarized in figure 2.

To gather more information about authors, affiliations such as "college or university library" or "LIS school" were coded. These affiliations were more widely documented and provided insight that was absent in the review of author positions. Sixty-one percent of the 239 authors were affiliated with a college or university library, more than 20 percentage points higher than the number of authors who were specifically identified as librarians in the author title classification. Thirteen percent of authors were affiliated with an LIS graduate program, and 13 percent were affiliated with a college or university without a specific title or department listed. Seven percent of authors identified as faculty from other department and schools, such as the Department of Mathematics and Statistics, Faculty of Humanities and Social Sciences, and School of Computer and Security Science. See table 2 for more detail on author affiliation.

\begin{tabular}{|l|c|c|}
\hline \multicolumn{3}{|c|}{ TABLE 2 } \\
\hline Affiliation Category & Number of Authors & Percentage of Total Authors \\
\hline College or University Library & 146 & $61 \%$ \\
\hline LIS Graduate Program & 30 & $13 \%$ \\
\hline College or University & 31 & $13 \%$ \\
\hline Other Schools and Departments & 17 & $7 \%$ \\
\hline Unknown & 6 & $3 \%$ \\
\hline Community College Library & 5 & $2 \%$ \\
\hline Other & 4 & $2 \%$ \\
\hline TOTAL & $\mathbf{2 3 9}$ & $\mathbf{1 0 0 \%}$ \\
\hline
\end{tabular}

Although 54 percent of the selected publications were written by a single author, the remaining 46 percent represent various forms of collaborative authorship. Twentyone of the publications (14\%) were the result of authors from different universities or institutions working together. This includes authors from two different universities, as well as authors from, for example, a university and a government agency. Twenty-one (14\%) of the collaborations were categorized as "within university." However, this code did not include collaborations within the library, only those between the library and another office or department. Surprisingly, "in library" collaborations were slightly less common than "within university," at 19 (12\%). In a few cases, no information was provided about author affiliations, but multiple authors indicated collaboration. These 10 publications were coded as "unknown collaboration type." Some articles fit into more than one category when it came to collaboration. For example, an article written by two authors from the same library and one author from another university would be classified as "in library" and "between institutions," so these classifications overlap in some cases. For this reason, the numbers in table 3 do not add up to 147 total articles, nor do the percentages equal 100 percent. Only six of the articles were the result of international collaborations, but research partnerships were evident between universities in the United States and South Korea, ${ }^{32}$ Australia and Canada, ${ }^{33}$ and the United States and China. ${ }^{34}$ 


\begin{tabular}{|l|c|c|}
\hline \multicolumn{3}{|c|}{ TABLE 3 } \\
Numbers and Percentages of Publications by Collaboration Types \\
\hline Collaboration Type & $\begin{array}{c}\text { Number of } \\
\text { Publications }\end{array}$ & $\begin{array}{c}\text { Percentage of Total } \\
\text { Publications }\end{array}$ \\
\hline Single Author & 83 & $54 \%$ \\
\hline Between Institutions & 21 & $14 \%$ \\
\hline Within University & 21 & $14 \%$ \\
\hline In Library & 19 & $12 \%$ \\
\hline Unknown Collaboration Type & 10 & $6 \%$ \\
\hline International Collaborations & 6 & $4 \%$ \\
\hline
\end{tabular}

The majority of authors (66\%) were affiliated with universities and institutions in the United States. Eleven other countries appeared in the analysis for author affiliation: Australia, Canada, China, Ireland, New Zealand, Nigeria, Qatar, South Korea, Sweden, the United Arab Emirates, and the United Kingdom. Australian (13\%) and Canadian $(8 \%)$ institutional affiliations were the most common behind the United States. See table 4 for the number of authors from each country.

\begin{tabular}{|l|c|c|}
\hline \multicolumn{2}{|c|}{ TABLE 4 } \\
\hline Country of Affiliation & Number of Authors & Percentage of Total Authors \\
\hline United States & 158 & $66.1 \%$ \\
\hline Australia & 31 & $13.0 \%$ \\
\hline Canada & 20 & $8.4 \%$ \\
\hline China & 8 & $3.3 \%$ \\
\hline United Kingdom & 8 & $3.3 \%$ \\
\hline Ireland & 3 & $1.3 \%$ \\
\hline South Korea & 3 & $1.3 \%$ \\
\hline Sweden & 3 & $1.3 \%$ \\
\hline New Zealand & 1 & $0.4 \%$ \\
\hline Nigeria & 1 & $0.4 \%$ \\
\hline Qatar & 1 & $0.4 \%$ \\
\hline United Arab Emirates & 1 & $0.4 \%$ \\
\hline Unknown & 1 & $0.4 \%$ \\
\hline TOTAL & $\mathbf{2 3 9}$ & $\mathbf{1 0 0 . 0 \%}$ \\
\hline
\end{tabular}

\section{Research Classification}

Of the 147 publications, 70 (48\%) were identified as original research, while 77 (52\%) did not meet the criterion to be labeled this way. Only publications that included a methods or methodology section in the main text were considered original research. Certain exceptions were made for journals published outside of the United States that use a different format for scholarly publications. In a few cases, the articles were clearly reporting on original research but did not contain a section explicitly labeled "Methods" or "Methodology." Of the 77 nonoriginal research publications, only 38 were 
"what we did" articles, usually describing a specific project or program developed by a library to better meet the information needs of international students. The remaining 39 articles were generally literature reviews or best practices and summarized recommendations for supporting international student populations. This group will be referred to as general literature.

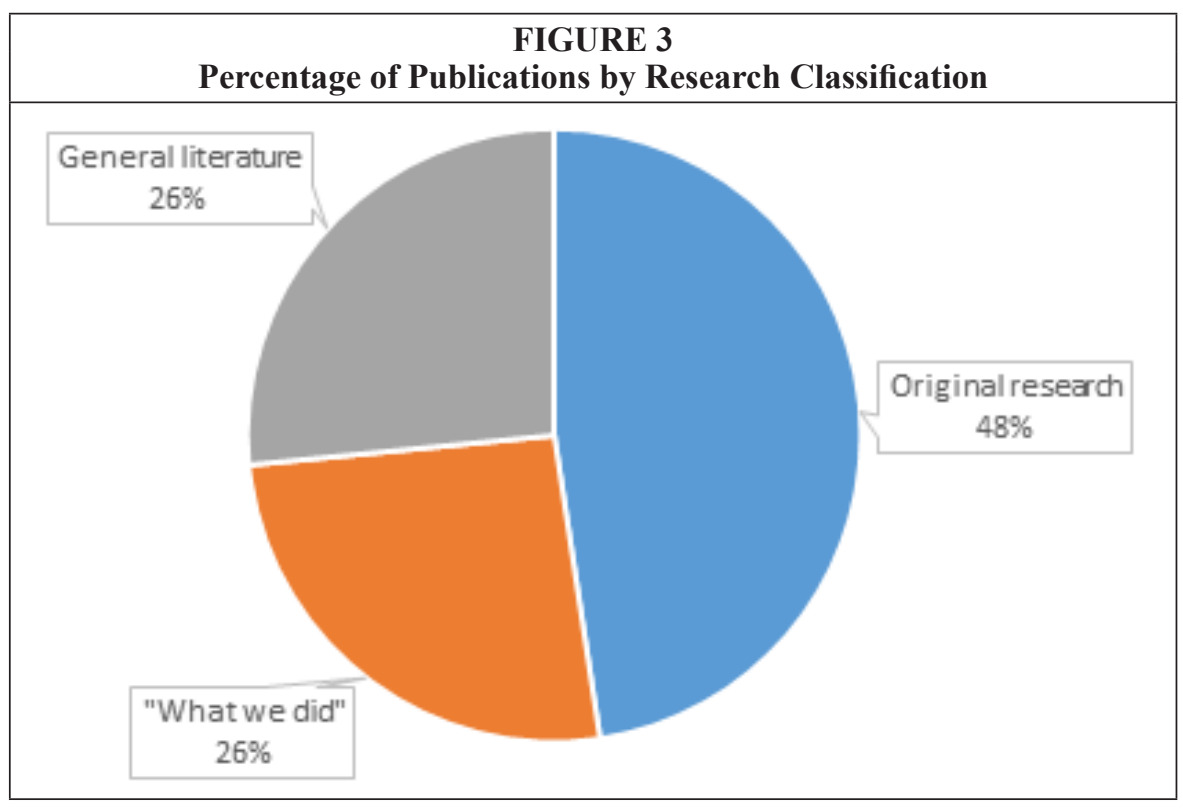

\section{Research Methods and Theories}

The analysis of the research methods used to study international students in academic libraries is perhaps the most useful and valuable result of this study. As the criterion for original research was the presence of a methods section, only the 70 articles labeled in this way are included in the research methods analysis. Surveys were by far the most widely used research method. Forty-seven of these $70(67 \%)$ research articles used surveys-either online, print, or as part of a mixed-methods study. This is not surprising given the growth and development of online survey and data analysis tools, such as Survey Monkey and Qualtrics. Interviews were the second most popular, and 21 studies (30\%) used this method either as the sole method or as part of a mixed-method design. Testing was used in four of the studies, albeit by slightly different names such as skills testing, ${ }^{35}$ multiple choice testing, ${ }^{36}$ or pre- and post-testing. ${ }^{37}$ Eighteen $(26 \%)$ of the studies used mixed research methods including different combinations of the following: surveys, testing, writing analysis, ${ }^{38}$ focus groups, ${ }^{39}$ interviews, ${ }^{40}$ website content analysis ${ }^{41}$ research portfolios, ${ }^{42}$ key tracking, ${ }^{43}$ and collection usage statistics. ${ }^{44}$ Within the mixed method category, all 18 of the studies used surveys or interviews combined with other methods. In a couple of cases, the research design called for an unusual method such as biographical narrative ${ }^{45}$ or field stimulation. ${ }^{46}$ Occasionally an uncommon method appeared in more than one publication, but typically this was the result of multiple papers that were published about the same study.

Very few studies used any sort of theory to frame the research. Of the seven articles that did reference some sort of theory, model, or framework, one used second-language acquisition theories, ${ }^{47}$ another used self-directed language learning, ${ }^{48}$ and yet another 
used the concept of acculturation. ${ }^{49}$ LIS models, such as everyday life information seeking, ${ }^{50}$ Wilson's model of information behavior, ${ }^{51}$ and Bruce's relational model of information literacy, ${ }^{52}$ appeared only four times.

\section{Study Location and Population}

Research location and details about the study population were recorded for all 147 publications, whether or not the article met the criteria for original research. While those reporting on original research generally provided locations and information about the study population such as status (example: undergraduate students) and country of origin, in some cases publications in the "what we did" and general literature categories did as well. For example, an article categorized as "what we did" detailed an information literacy program developed at a university in Ireland, for students from Pakistan and China. ${ }^{53}$ For publications like this, it was possible to identify location and country of origin despite the lack of the original research designation.

More than half of the 147 publications reviewed did not provide study locations. Forty $(27 \%)$ of the studies took place in the United States, distantly followed by Canada $(7 \%)$, Australia (6\%), and China (4\%). One study took place in both the United States and Canada, which is why the total number of publications in table 5 is 148 instead of $147 .{ }^{44}$

\begin{tabular}{|l|c|c|}
\hline \multicolumn{2}{|c|}{$\begin{array}{c}\text { TABLE 5 } \\
\text { Numbers and Percentages of Publications by Study Location Country }\end{array}$} \\
\hline Study Location Country & Number of Publications & $\begin{array}{c}\text { Percentage of Total } \\
\text { Publications }\end{array}$ \\
\hline United States & 40 & $27 \%$ \\
\hline Canada & 10 & $7 \%$ \\
\hline Australia & 9 & $6 \%$ \\
\hline China & 6 & $4 \%$ \\
\hline United Kingdom & 3 & $2 \%$ \\
\hline Nigeria & 1 & $1 \%$ \\
\hline Sweden & 1 & $1 \%$ \\
\hline United Arab Emirates & 1 & $1 \%$ \\
\hline Ireland & 1 & $1 \%$ \\
\hline Not Applicable & 76 & $51 \%$ \\
\hline TOTAL & $\mathbf{1 4 8}$ & $\mathbf{1 0 0 \%}$ \\
\hline
\end{tabular}

Study populations were coded for both country of origin (for example, China) and type (such as graduate students). Some of the studies selected specific groups of international students as the target population. A breakdown of the study population country of origin showed that $51(35 \%)$ of the articles reviewed targeted a "mixed" group of international students. Study population was deemed "mixed" if the author(s) identified the population simply as "international students." When specific countries of origin were targeted, almost all of the studies focused on students from Asia. Thirteen studies focused on students from countries such as Japan, ${ }^{55}$ China, ${ }^{56}$ and South Korea, ${ }^{57}$ which may be a result of the large number of studies conducted by researchers in the United States and Australia, both of which house an increasing number of Asian students. ${ }^{58}$ One article, a "what we did" paper about collection development for international students, focused on Somali students. ${ }^{59}$ For $78(53 \%)$ of the articles, popu- 
lation country of origin was coded as "not applicable" because no mention was made of a study population, usually because the article did not qualify as original research.

Sixty-two of these 147 publications (42\%) used various student groups as the selected research population. Within these 62, more than half (35) looked at populations made up of both undergraduate and graduate students, 8 undergraduate students only, and 13 graduate students only. In eight of the publications, academic librarians were included in the targeted population. Seven studies used mixed populations, made up of some combination of faculty, staff, administrators, students, and librarians. For example, one article about outreach to international students involved surveying undergraduate and graduate students, as well as faculty and staff. ${ }^{60}$

\section{Research Topics}

Twenty-seven different codes were identified for the publication topics. Many appeared only once in the study, such as writing, computer literacy, mobile devices, and health information. The 12 most popular topics are shown in table 6 . All topics ranked below the top 12 appeared five or fewer times.

\begin{tabular}{|l|c|c|}
\hline \multicolumn{3}{|c|}{ TABLE 6 } \\
Numbers and Percentages of Publications by Most Popular Research Topics \\
\hline Topic & $\begin{array}{c}\text { Number of } \\
\text { Publications }\end{array}$ & $\begin{array}{c}\text { Percentage of Total } \\
\text { Publications }\end{array}$ \\
\hline Information Literacy/Library Instruction & 66 & $45 \%$ \\
\hline Library Experience & 41 & $28 \%$ \\
\hline Language Issues & 36 & $24 \%$ \\
\hline Library Services & 23 & $16 \%$ \\
\hline Multicultural/Intercultural Issues & 23 & $16 \%$ \\
\hline Outreach & 19 & $13 \%$ \\
\hline Information Seeking & 17 & $12 \%$ \\
\hline Online Library Resources & 14 & $10 \%$ \\
\hline Collaboration & 11 & $7 \%$ \\
\hline Language Learning & 11 & $7 \%$ \\
\hline Information Behavior & 10 & $7 \%$ \\
\hline Librarian Training & 8 & $5 \%$ \\
\hline
\end{tabular}

The "library experience" category includes any research that asked about perceptions of or experiences in any library. Most focused on the academic library of the college or university in which the international students are studying abroad. ${ }^{61}$ However, some explored the students' experiences in their home countries. ${ }^{62}$ The "language issues" category focuses on the challenges of providing services for students with varying levels of English-language proficiency, ${ }^{63}$ while "language learning" refers to library support for international students developing language skills. ${ }^{64}$ "Information behavior" was used to indicate more general behaviors, such as the use of social media by international students ${ }^{65}$ or how these students meet their information needs. ${ }^{66}$ The "information seeking" category was used for more specific information tasks, like completing an assignment, ${ }^{67}$ or tasks assigned by the researcher. ${ }^{68}$ "Library services" and "reference services" are separate categories because some studies explored a va- 
riety of library services, from information literacy instruction to interlibrary loan, and others focused only on reference services. "Multicultural/intercultural issues" covered a variety of subtopics, including learning preferences and cultural differences. This code was much more prevalent in the literature from the 1990s, because publications about international students were more often general overviews of the topic.

\section{Discussion}

This section provides further exploration of authorship trends, publication impact, further research, study implications, and limitations.

\section{Original Research}

Similar to previous research, our findings showed that surveys were by far the most widely used research method. This matches the findings of a content analysis by Turcios, Agarwal, and Watkins, in which surveys were the most frequently used method in 307 LIS research articles. ${ }^{69}$ This potentially raises questions of quality and depth of research in the LIS field. Surveys provide librarians and other LIS researchers access to quick and easily formed datasets, but they may not always be the best method to address the research question(s). From 2010 to 2014, several research methods made an appearance for the first time-including collection usage statistics, biographical narrative, research portfolios, and flowcharts - and more multifaceted studies were conducted. This may be related to the 2010 publication of The Value of Academic Libraries, which called upon the academic library community to set research agendas, assess their impact, and communicate change..$^{70}$

Of the 98 publications with at least one author affiliated with a U.S. institution, only 38 were considered original research. Thus, 61 percent of the literature on international students in academic libraries published by U.S. authors qualifies as either "what we did" pieces or general literature. By comparison, 62 percent of the publications with at least one Australian author are original research. Why aren't U.S. authors publishing more original research? Potentially they lack the needed resources, specifically time, to conduct original research. Or perhaps there is simply not as much interest in conducting original research among LIS practitioners in the United States, particularly those who are non-tenure-track academic librarians. Overall, however, the publication of original research has increased between 1990 and 2014. Seventy of the 147 (48\%) analyzed publications were classified as original research. But for articles published between 1995 and 1999, only 35 percent were original research, and by 2011-2014 that number had increased to 56 percent. See table 7 for more information.

\begin{tabular}{|l|c|c|c|}
\hline \multicolumn{4}{|c|}{$\begin{array}{c}\text { TABLE 7 } \\
\text { Numbers and Percentages of Original Research Publications for 5 Year } \\
\text { Periods, 1990-2014 }\end{array}$} \\
\hline & Total Publications & $\begin{array}{c}\text { Original Research } \\
\text { Publications }\end{array}$ & $\begin{array}{c}\text { Percentage of Total } \\
\text { Publications }\end{array}$ \\
\hline $1995-1999$ & 23 & 8 & $35 \%$ \\
\hline $1990-1994$ & 14 & 7 & $50 \%$ \\
\hline $2000-2004$ & 23 & 7 & $30 \%$ \\
\hline $2005-2010$ & 37 & 20 & $54 \%$ \\
\hline $2011-2014$ & 50 & 28 & $56 \%$ \\
\hline TOTAL & $\mathbf{1 4 7}$ & $\mathbf{7 0}$ & $\mathbf{4 8 \%}$ \\
\hline
\end{tabular}




\section{Trends in Authorship}

The dataset also shows that LIS literature has become more collaborative over the past 25 years. We identified 23 publications for this systematic review published between 1990 and 1999, as well as 50 published between 2010 and 2014. Of the first 23 publications, $17(74 \%)$ were coded as single author, but only 26 of the last $50(52 \%)$ received this designation. See figure 4 for more detail on the decline of single authorship. All six of the journal articles written by authors located in different countries were published between 2007 and 2014. This is to be expected, however, as global communication has become much easier and cheaper over the last 25 years.

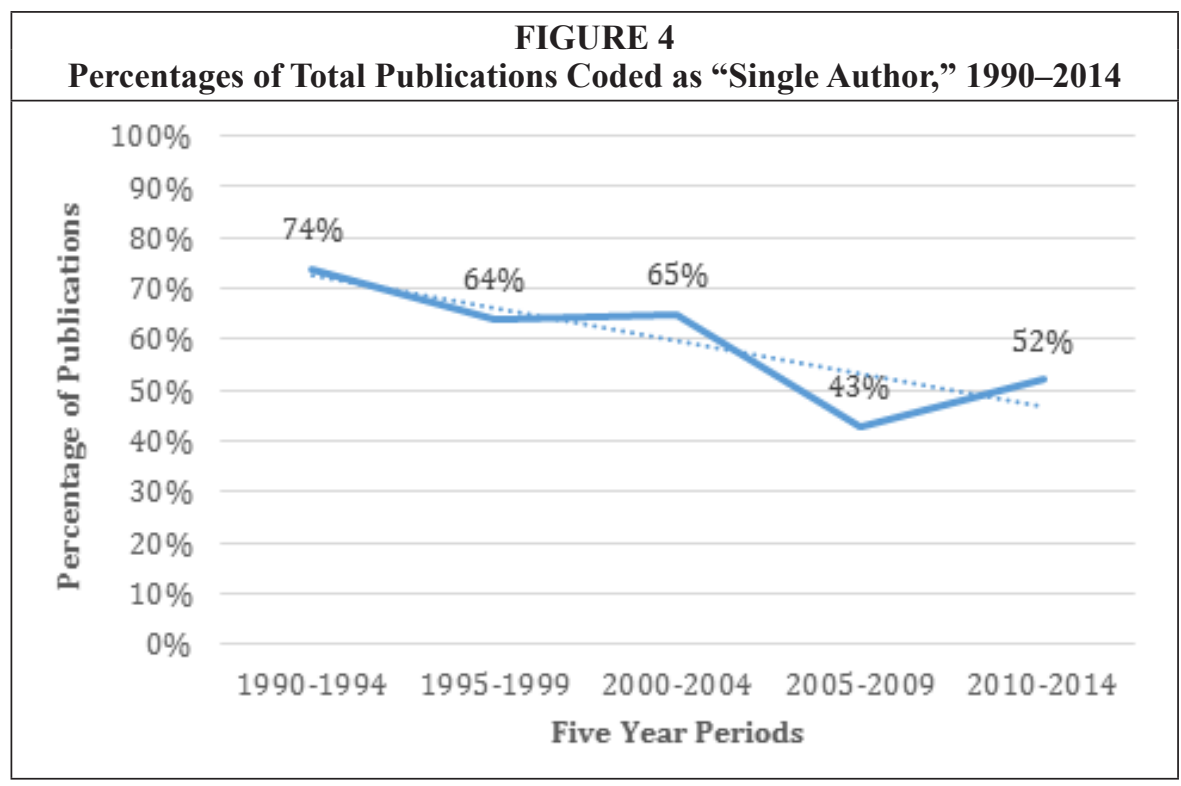

Overall, 66 percent of the 239 authors included in this systematic review are affiliated with an institution in the United States. This number dropped a bit between 1990 and 2014, but by fewer than 10 percentage points. Table 8 shows the number of U.S.-affiliated authors for each 5-year period. For publications between 1990 and 1994, only authors from the United States, Australia, and the United Kingdom were represented. Diversity of authors increased over the years, however, and publications from 2011 to 2014 were produced by authors from the United States, Australia, Canada, China, Sweden, the United Kingdom, South Korea, Qatar, and United Arab Emirates. This increase in diversity of published authors indicates a broader interest in the globalization of higher education. As more universities compete for international students, there is likely to be continued interest in academic libraries supporting international students, as well as demonstrating their value through assessment activities resulting in publications.

\section{Impactful Publications}

This body of literature could be overwhelming for the academic librarian looking for practical guidance. A brief discussion of the specific findings and recommendations from the most impactful publications included in the study may help alleviate this burden. In this case, impact was determined by citation numbers from Google Scholar, and the eight most-cited articles from the list of 147 are discussed below. These eight articles were each coded with one of the top three occurring topics: information literacy/ 


\begin{tabular}{|c|c|c|c|}
\hline \multicolumn{4}{|c|}{$\begin{array}{c}\text { TABLE } 8 \\
\text { Numbers and Percentages of Authors with U.S. Institutional Affiliation } \\
\text { for } 5 \text { Year Periods, 1990-2014 }\end{array}$} \\
\hline & $\begin{array}{c}\text { Total Number of } \\
\text { Authors }\end{array}$ & $\begin{array}{c}\text { Authors with U.S. } \\
\text { Affiliation }\end{array}$ & $\begin{array}{c}\text { Percentage of Total } \\
\text { Authors }\end{array}$ \\
\hline 1995-1999 & 21 & 15 & $71 \%$ \\
\hline 1990-1994 & 28 & 21 & $75 \%$ \\
\hline 2000-2004 & 31 & 23 & $74 \%$ \\
\hline 2005-2010 & 72 & 45 & $63 \%$ \\
\hline 2011-2014 & 87 & 54 & $62 \%$ \\
\hline TOTAL & 239 & 158 & $66 \%$ \\
\hline
\end{tabular}

library instruction, library experience, or language issues. Three of these top-cited articles were published prior to 2000, and five between 2000 and 2014. Looking at the most highly cited articles in chronological order demonstrates the changes in the needs and competencies of international students as well as the ways libraries have attempted to reach and serve this user group. All but the first of the publications report the results of original research.

Kalin's 1992 book chapter, "The International Student in the American Academic Library," highlights the challenges of communication, cultural differences, learning styles, and prior experience with libraries that international students often face. She makes some of the same recommendations that Liu does (see below), such as tours and librarian training, but also recommends collection development efforts as an opportunity to better serve international students. There was no study conducted as part of the research for this chapter; Kalin relies on the literature to support conclusions and recommendations. ${ }^{71}$

Allen's 1993 study is the earliest highly cited article in our list of selected publications that specifically studies the library experience of international students. A random sample of international students at the University of Illinois at Urbana-Champaign completed a questionnaire regarding different aspects of their experience with library services and facilities, including use of the online catalog and library computers. The participants, of whom 91.6 percent were graduate or doctoral students, represented a wide range of countries, although the majority were from Asian countries. The top three aspects of libraries identified as new and unfamiliar by the participants were interlibrary loan, computer database literature searching, and term paper research counseling. Allen recommends that each library evaluate the needs of the specific populations it serves to meet their specific needs. ${ }^{72}$

In another 1993 study, Liu interviewed international students, mostly from Asian countries, at the University of California, Berkeley. Liu advocates for the interview method to avoid misunderstandings common in written self-administered surveys. Language issues were identified as a significant barrier for this group when using the library. Other barriers found were related to unfamiliarity with American-style libraries. Open stacks, different classification systems, and reference works were unfamiliar and proved challenging for participants. To overcome these barriers, Liu recommends creating glossaries of library terminology, offering library tours and hands-on workshops for international students, and fostering cultural sensitivity in library staff. ${ }^{73}$

Baron and Strout-Dapaz's 2001 article, "Communicating With and Empowering International Students with a Library Skills Set," has been cited more than 100 times. The authors surveyed university libraries and international student offices to deter- 
mine how to best serve this population. Respondents in both groups noted language/ communication problems, adjusting to a new educational/library system, and general cultural adjustment as the three major challenges facing international students. The authors use the ACRL Standards for Information Literacy to suggest ways to address the challenges facing international students. ${ }^{74}$

Jackson's well-known 2005 study found that most international students were highly computer-literate and had used libraries in their home country, a significant change compared to the results of studies conducted in the 1990s. Her recommendations are to create partnerships with international student offices on campus and to increase outreach efforts to this population. Other suggestions include creating online guides and tutorials and training library staff. ${ }^{75}$

In a study using stimulation method published in 2005, Curry and Copeman examined reference services for international students. The study design is particularly interesting, as the focus on reference services and the chosen method are not often found in this subset of the literature. While several aspects of reference services were discussed, language issues were the main focus. The study revealed the benefits repeating and rephrasing, explanation and instruction, and avoiding library jargon during a reference interview with international students. Early termination of the reference interview was noted as a reason a user may not return to that librarian with future questions. ${ }^{76}$

In their 2007 study, Liao, Finn, and Lu investigated the information-seeking behavior of international and American graduate students at Virginia Tech using a survey. This study found that international students were much more frequent and active library users than their American peers. International students were much more likely to participate in a library workshop or orientation, viewing the library itself as a "social gathering place." 77 The authors note the progress that has been made with libraries serving international students. The technological barriers have decreased, as has the stigma or confusion about asking a librarian for assistance that has been reported in past studies.

\section{Implications and Further Research}

This study has implications for the LIS field in two ways, one related to research and one to practice. First, we hope that the study design will encourage LIS researchersespecially those in subfields outside the health sciences - to consider the systematic review a valuable and feasible method. As Petticrew and Roberts note, the method is particularly useful when an overall picture of the evidence and past research is needed to inform future research and the development of methodologies. ${ }^{78}$ Thus, the use of systematic review could encourage innovative work in the LIS field, allowing practitioners and scholars to better understand trends and best practices related to collection, instruction, outreach, assessment, and much more. In addition, the findings of this study demonstrate a lack of original research in the LIS literature. For example, of the 66 publications about information literacy/library instruction, 33 were categorized as original research. Many of the 33 publications that do not qualify as original research recount library programs such as orientation or one-shot instruction sessions designed for international students. If program assessment is not conducted or reported, these publications may be of limited use to readers searching for effective ways to serve international student populations.

Second, this systematic review is intended to support LIS practitioners in their efforts to support international students by providing a comprehensive guide to the literature on this population. As librarians strive to make evidence-based decisions to improve practice, the systematic review can be used as a tool to make scaling the "information mountain" less intimidating. ${ }^{79}$ 
This study shows that academic librarians and other scholars have and will continue to pay close attention to information needs and research experiences of international students, but further research is needed to identify best practices for teaching, serving, and understanding this population. We recommend that those publishing in the LIS field on this topic focus on well-designed, replicable, original research. In addition, careful consideration of research methods to identify the most appropriate choice for a particular study would likely improve the quality and depth of research. The research topics identified in this study indicate some areas where further research is needed. For example, identifying best practices for meeting the information needs of international students-perhaps through a large multifaceted study - would be a significant and welcome contribution to the LIS literature.

\section{Limitations}

Although this systematic review was designed to be comprehensive, we acknowledge that there are some limitations to this research. The study reviewed only Englishlanguage publications in three major Western databases, including Library $\mathcal{E}$ Information Science Source (LISS), Library and Information Science Abstracts (LISA), and Library, Information Science \& Technology Abstracts (LISTA), and the publications identified in the manual bibliography search. All non-English-language articles that appeared in the results list were excluded. Analyzing research published in other languages could address some of the gaps of author location and study location and paint a more complete picture of the information needs and academic library experiences of international students studying all over the world.

\section{Conclusion}

This systematic review of the literature established that the LIS literature on international students is limited but growing. Study findings show that single authorship has declined and that international collaborations are becoming more common. The body of literature is heavily focused on library instruction/information literacy and library experiences of international students, but original research is lacking. As it is unlikely that the number of international students studying in the United States will begin to decline anytime soon, there are ample opportunities for further research. 


\section{Appendix A. All Publications by Category}

\section{Journal Articles}

Ademodi, Olugbengo. "Reference Service in Academic Libraries: Accommodation of International Students." Library Philosophy \& Practice (2011): 1-10. http://digitalcommons.unl.edu/ libphilprac/.

Aihong, Fan. "Creating a Bilingual Library Information Environment for Foreign Users." The Electronic Library 27, no. 2 (2009): 237-46. doi:10.1108/02640470910947584.

Allen, Mary Beth. "International Students in Academic Libraries: A User Survey." College \& Research Libraries 54, no. 4 (1993): 323-33. doi:10.5860/crl_54_04_323.

Amsberry, Dawn. "Deconstructing Plagiarism: International Students and Textual Borrowing Practices." Reference Librarian 51, no. 1 (2009): 31-44. doi:10.1080/02763870903362183.

Amsberry, Dawn. "Talking the Talk: Library Classroom Communication and International Students." The Journal of Academic Librarianship 34, no. 4 (2008): 354-57. doi:10.1016/j.acalib.2008.05.007.

Amsberry, Dawn. "Using Effective Listening Skills with International Patrons." Reference Services Review 37, no. 1 (2009): 10-19. doi:10.1108/00907320910934959.

Badke, William. "International Students: Information Literacy or Academic Literacy?" Academic Exchange 6, no. 4 (2002): 60-66.

Baron, Sara, and Alexia C. Strout-Dapaz. "Communicating with and Empowering International Students with a Library Skills Set." Reference Services Review 29, no. 4 (2001): 314-26. doi:10.1108/00907320110408447.

Blas, Elise A. "Information Literacy in the 21st Century Multicultural Classroom: Using Sociocultural Literacy." Education Libraries 37, no. 1/2 (2014): 33-41.

Boers, Greta G. “Designing a Library Instruction Program for International Students." Georgia Librarian 31, no. 4 (1994): 92-96.

Bordonaro, Karen. "Exploring the Connections between Information Literacy and Writing for International Students." Journal of Information Literacy 2, no. 2 (2008): 1-17. doi:10.11645/2.2.67.

Bordonaro, Karen. "Is Library Database Searching a Language Learning Activity?" College \& Research Libraries 71, no. 3 (2010): 273-84. doi:10.5860/0710273.

Bordonaro, Karen. "Language Learning in the Library: An Exploratory Study of ESL Students." The Journal of Academic Librarianship 32, no. 5 (2006): 518-26. doi:10.1016/j.acalib.2006.06.009.

Bordonaro, Karen. "Recreational Reading of International Students in Academic Libraries." The Reading Matrix: An International Online Journal 11, no. 3 (2011), 269-78. http://www.readingmatrix.com/.

Brown, Christopher C. "Reference Services to the International Adult Learner: Understanding the Barriers." The Reference Librarian 33, no. 69/70 (2000): 337-47. doi:10.1300/J120v33n69_30.

Buckner, Terry, and Tiana French. "International Students and the Academic Library: How One Library Is Working to Make Its International Students Feel at Home." Kentucky Libraries 71, no. 2 (2007): 8-11.

Chakraborty, Mou, and Johanna Tuñó. "Taking the Distance Out of Library Services Offered to International Graduate Students: Considerations, Challenges, and Concerns." Journal of Library Administration 37, no. 1/2 (2002): 163-76. doi:10.1300/J111v37n01_15.

Chattoo, Calmer D. "Reference Services: Meeting the Needs of International Adult Learners." The Reference Librarian 33, no. 69/70 (2000): 349-62. doi:10.1300/J120v33n69_31.

Chau, May Ying. "Helping Hands: Serving and Engaging International Students." The Reference Librarian 38, no. 79/80 (2002): 383-93. doi:10.1300/J120v38n79_26.

Chen, Yao, and Cecelia Brown. "Ensuring Chinese Engineering Graduate Students' Academic Success: A Study at the University of Oklahoma." Science \& Technology Libraries 31, no. 3 (2012): 320-41. doi:10.1080/0194262X.2012.705144.

Chen, Yu-Hui, and Mary K. Van Ullen. "Helping International Students Succeed Academically through Research Process and Plagiarism Workshops." College \& Research Libraries 72, no. 3 (2011): 209-35. doi:10.5860/crl-117rl .

Chin, Susan Ho. “Collaborative Library Research: A Learning Process for ESL Students.” Teaching English in the Two-Year College 21, no. 1 (1994): 47--52.

Conteh-Morgan, Miriam E. "Empowering ESL Students: A New Model for Information Literacy Instruction." Research Strategies 18, no. 1 (2001): 29-38. doi:10.1016/S0734-3310(02)00064-2.

Conteh-Morgan, Miriam. "Connecting the Dots: Limited English Proficiency, Second Language Learning Theories, and Information Literacy Instruction." The Journal of Academic Librarianship 28, no. 4 (2002): 191-96. doi:10.1016/S0099-1333(02)00282-3.

Curry, Ann, and Deborah Copeman. "Reference Service to International Students: A Field Stimulation Research Study." The Journal of Academic Librarianship 31, no. 5 (2005): 409-20. 
doi:10.1016/j.acalib.2005.05.011.

Datig, Ilka."What Is a Library? International College Students' Perceptions of Libraries." The Journal of Academic Librarianship 40, no. 3/4 (2014): 350-56. doi:10.1016/j.acalib.2014.05.001.

Davis, Harry O. "Map Librarians, the International Student, and ESL: Opportunity and Challenge." Bulletin (Special Libraries Association Geography \& Map Division), no. 169 (1992): 17-28.

De Souza, Yvonne. "Reference Work with International Students: Making the Most Use of the Neutral Question." Reference Services Review 24, no. 4 (1996): 41-48. doi:10.1108/eb049295.

Farrell, Shannon L., Catherine L. Cranston, and Jeffrey S. Bullington. "Embracing INTO: Library Plans and Campus Collaboration to Serve an Increased International Student Population." Collaborative Librarianship 5, no. 2 (2013): 101-21. http://collaborativelibrarianship.org/.

Ferrer-Vinent, Ignacio J. “For English, Press 1: International Students' Language Preference at the Reference Desk." The Reference Librarian 51, no. 3(2010): 189-201. doi:10.1080/02763871003800429.

Ganster, Ligaya. "Reaching Out to International Students: A Focus-Group Approach to Developing Web Resources and Services." College \& Undergraduate Libraries 18, no. 4 (2011): 368-84. doi:10.1080/10691316.2011.624933.

Garcha, Rajinder, and Patricia Yates Russell. "Bibliographic Instruction for International Students in Academic Libraries." Library Review 42, no. 6 (1993): 14--22. doi:10.1108/00242539310045426.

Gilton, Donna C. "A World of Difference: Preparing for Information Literacy Instruction for Diverse Groups." Multicultural Review 3, no. 3 (1994): 54-55.

Gunnarsson, Jenny, Wlodek J. Kulesza, and Anette Pettersson. “Teaching International Students How to Avoid Plagiarism: Librarians and Faculty in Collaboration." The Journal of Academic Librarianship 40, no. 3/4 (2014): 413-17. doi:0.1016/j.acalib.2014.04.006.

Han, Jinghe. "The Experiences of Chinese PhD Students in Australia: Encountering Information Literacy Challenges." Journal of Information Literacy 6, no. 1 (2012): 3-17. doi:10.11645/6.1.1603.

Han, Ning, and Susan L. Hall. "Think Globally! Enhancing the International Student Experience with LibGuides." Journal of Electronic Resources Librarianship 24, no. 4 (2012): 288-97. doi:10.1 080/1941126X.2012.732512.

Helms, Cynthia Mae. "Reaching Out to the International Students through Bibliographic Instruction." The Reference Librarian 24, no. 51/52 (1995): 295-307. doi:10.1300/J120v24n51_28.

Howze, Philip C., and Dorothy M. Moore. "Measuring International Students' Understanding of Concepts Related to the Use of Library-based Technology." Research Strategies 19, no. 1 (2003): 57-74. doi:10.1016/S0734-3310(03)00005-3.

Hughes, Hilary, and Christine Bruce. "Cultural Diversity and Educational Inclusivity: International Students' Use of Online Information." International Journal of Learning 12, no. 9 (2006): 33-40.

Hughes, Hilary. "Actions and Reactions: Exploring International Students' Use of Online Information Resources." Australian Academic \& Research Libraries 36, no. 4 (2005): 169-79. doi:10.1 080/00048623.2005.10755308.

Hughes, Hilary. "An Expanded Critical Incident Approach for Exploring Information Use and Learning." Library and Information Research 36, no. 112 (2012): 72-95. http://www.lirgjournal. org.uk/lir/ojs/index.php/lir/index.

Hughes, Hilary. "International Students' Experiences of University Libraries and Librarians." Australian Academic \& Research Libraries 41, no. 2 (2010): 77-89. doi:10.1080/00048623.2010.10721446.

Hughes, Hilary. "International Students Using Online Information Resources to Learn: Complex Experience and Learning Needs." Journal of Further and Higher Education 37, no. 1 (2013): 126-46. doi:10.1080/0309877X.2011.644778.

Hurley, Tina, Nora Hegarty, and Jennifer Bolger. “Crossing a Bridge: The Challenges of Developing and Delivering a Pilot Information Literacy Course for International Students." New Library World 107, no. 7/8 (2006): 302-20. doi:10.1300/J120v38n79_26.

Irving, Suzanne. "Addressing the Special Needs of International Students in Interlibrary Loan: Some Considerations." The Reference Librarian 21, no. 45/46 (1994): 111-17. doi:10.1300/ J120v21n45_12.

Ishimura, Y., and Bartlett. J.C. "Uncovering the Research Process of International Students in North America: Are They Different from Domestic Students?" Information Research 18, no. 1 (2013). http://www.informationr.net/ir/.

Ishimura, Yusuke, and Joan C. Bartlett. "Are Librarians Equipped to Teach International Students? A Survey of Current Practices and Recommendations for Training." The Journal of Academic Librarianship 40, no. 3 (2014): 313-21. doi:10.1016/j.acalib.2014.04.009.

Ishimura, Yusuke, Vivian Howard, and Haidar Moukdad. "Information Literacy in Academic Libraries: Assessment of Japanese Students' Needs for Successful Assignment Completion in Two Halifax Universities." Canadian Journal of Information \& Library Sciences 31, no. 1 (2007): 1-26.

Ishimura, Yusuke. "Information Behavior and Japanese Students: How Can an Understanding of the Research Process Lead to Better Information Literacy?" Public Services Quarterly 9, no. 1 (2013): 20-33. doi:10.1080/15228959.2013.758977. 
Jackson, Pamela A. "Incoming International Students and the Library: A Survey." Reference Services Review 33, no. 2 (2005): 197-209. doi:10.1108/00907320510597408.

Jiao, Qun G., and Anthony John Onwuegbuzie. “Sources of Library Anxiety among International Students." Urban Library Journal 11, no. 1 (2001): 16-26.

Jiao, Shuqin, Fu Zhuo, Liming Zhou, and Xiaoying Zhou. "Chinese Academic Libraries from the Perspective of International Students Studying in China." The International Information \& Library Review 41, no. 1 (2009): 1-11. doi:10.1016/j.iilr.2008.07.007.

Joyce, Angela. "Dear Mr. Angela": Engaging with International Students at the University of Bristol." ALISS Quarterly 7, no. 4 (2012): 28-31.

Knight, Lorrie, Maryann Hight, and Lisa Polfer. "Rethinking the Library for the International Student Community." Reference Services Review 38, no. 4 (2010):581-605. doi:10.1108/00907321011090746.

Koenigstein, David. "Alleviating International Students' Culture Shock and Anxiety in American Academic Libraries: Welcome, Ahlan Wa Sahlan, Anyeong Hae Sae Yo, Bienvenidos, Huan ying, Sanu Da Zuwa, Shalom, Swaagat hai." Library Philosophy \& Practice (2012). http://digitalcommons.unl.edu/libphilprac/.

Korolev, Svetlana. "Chemical Information Literacy: Integration of International Graduate Students in the Research." Science \& Technology Libraries 19, no. 2 (2000): 35-42. doi:10.1300/ J122v19n02_04.

Kumar, Suhasini L., and Raghini S. Suresh. "Strategies for Providing Effective Reference Services for International Adult Learners." The Reference Librarian 33, no. 69/70 (2000): 327-36. doi:10.1300/J120v33n69_29.

Landers, Michael J., and Daryl C. Youngman. "Academic Libraries on the Front Lines: Advancing the Library through a Partnership with the U.S. Army." College \& Undergraduate Libraries 16, no. 2/3 (2009): 211-20. doi:10.1080/10691310903001481.

Lemmer, Catherine A. "A View from the Flip Side: Using the 'Inverted Classroom' to Enhance the Legal Information Literacy of the International LL.M. Student." Law Library Journal 105, no. 4 (2013): 461-91.

Liao, Yan, Mary Finn, and Jun Lu. "Information-Seeking Behavior of International Graduate Students vs. American Graduate Students: A User Study at Virginia Tech 2005." College E Research Libraries 68, no. 1 (2007): 5-25. doi:10.5860/crl.68.1.5.

Liestman, Daniel, and Connie Wu. "Library Orientation for International Students in Their Native Language." Research Strategies 8, no. 4 (1990): 191-96.

Liestman, Daniel. "Implementing Library Instruction for International Students." PNLA Quarterly 56, no. 2 (1992): 11-14.

Liestman, Daniel. "Reference Services and the International Adult Learner." The Reference Librarian 33, no. 69/70 (2001): 363-78. doi:10.1300/J120v33n69_32.

Lin, Mei-Yun Annie. "How Helping Chinese ESL College Students Write Research Papers Can Teach Information Literacy." Journal of East Asian Libraries, no. 141 (2007): 6-11. https://ojs.lib. byu.edu/spc/index.php/JEAL/index.

Liu, Guoying, and Danielle Winn. "Chinese Graduate Students and the Canadian Academic Library: A User Study at the University of Windsor." The Journal of Academic Librarianship 35, no. 6 (2009): 565-73. doi:10.1016/j.acalib.2009.08.001.

Liu, Jia. "International Students and the Chinese Academic Library: A User Survey at Beijing Normal University Library." The International Information \& Library Review 45, no. 1/2 (2013): 20-27. doi:10.1016/j.iilr.2013.08.001.

Liu, Mengxiong. "Library Services for Ethnolinguistic Students." Journal of Educational Media E Library Sciences 32, no. 3 (1995): 239-46.

Liu, Ziming. "Difficulties and Characteristics of Students from Developing Countries in Using American Libraries." College \& Research Libraries 54, no. 1 (1993): 25-31. doi:10.5860/ crl_54_01_25.

Lo, Mei Ling, Li Sun, Ryan Womack, Connie Wu, and Tao Yang. “Celebrating Diversity, Welcoming the World: Developing a Chinese Webpage at Rutgers University Libraries." CALA Occasional Paper Series, no. 5 (2009): 2-11.

Love, Emily, and Margaret B. Edwards. "Forging Inroads between Libraries and Academic, Multicultural and Student Services." Reference Services Review 37, no. 1 (2009): 20-29. doi:10.1108/00907320910934968.

Marama, Ishaya D. "Use of the Technological University Library by International Students.” The International Information \& Library Review 30, no. 2 (1998): 87-96. doi:10.1006/iilr.1998.0084.

Martin, Charity K., Charlene Maxey-Harris, Jolie Ogg Graybill, and Elizabeth K. Rodacker-Borgens. "Closing the Gap: Investigating the Search Skills of International and US Students: An Exploratory Study." Library Philosophy \& Practice (2009). http://digitalcommons.unl.edu/libphilprac/.

Martin, Julia A., Kathleen M. Reaume, Elaine M. Reeves, and Ryan D. Wright. "Relationship Building with Students and Instructors of ESL: Bridging the Gap for Library Instruction and 
Services." Reference Services Review 40, no. 3 (2012): 352-67. doi:10.1108/00907321211254634.

McClure, Jennifer, and Mangala Krishnamurthy. "Translating the Libraries: A Multilingual Information Page for International Students." Southeastern Librarian 55, no. 1 (2007): 26-31. http:// digitalcommons.kennesaw.edu/seln/.

McSwiney, Carolyn. "Academic Library Needs of Students from Non-English Speaking Backgrounds in Australia: A Position Paper and Select Bibliography." The Australian Library Journal 43, no. 3 (1994): 197-217. doi:10.1080/00049670.1994.10755689.

Meredith, Meri. "Confronting the Styles and Needs of an International Clientele." Information Outlook 3, no. 6 (1999): 18-22.

Moeckel, Nancy, and Jenny Presnell. “Recognizing, Understanding, and Responding: A Program Model of Library Instruction Services for International Students." The Reference Librarian 24, no. 51/52 (1995): 309-25. doi:10.1300/J120v24n51_29.

Morrissey, Renée, and Lisa M. Given. 2006. "International Students and the Academic Library: A Case Study." Canadian Journal of Information \& Library Sciences 30, no. 3/4: 221-39.

$\mathrm{Mu}$, Cuiying. "Marketing Academic Library Resources and Information Services to International Students from Asia." Reference Services Review 35, no. 4 (2007): 571-83. doi:10.1108/00907320710838390.

Mundava, Maud C., and LaVerne Gray. "Meeting Them Where They Are: Marketing to International Student Populations in U.S. Academic Libraries." Technical Services Quarterly 25, no. 3 (2008): 35-48. doi:10.1080/07317130802128627.

Natowitz, Allen. "International Students in US Academic Libraries: Recent Concerns and Trends." Research Strategies 13, no. 1 (1995): 4-16.

Nzivo, Charles N., and Chen Chuanfu. "International Students' Perception of Library Services and Information Resources in Chinese Academic Libraries." The Journal of Academic Librarianship 39, no. 2 (2013): 129-37. doi:10.1016/j.acalib.2012.11.004.

Onwuegbuzie, Anthony J., and Qun G. Jiao. "Academic Library Usage: A Comparison of Native and Non-native English-speaking Students." The Australian Library Journal 46, no. 3 (1997): 258-69. doi:10.1080/00049670.1997.10755807.

Park, Iljong. "A Comparative Study of Major OPACs in Selected Academic Libraries for Developing Countries-User Study and Subjective User Evaluation." The International Information $\mathcal{E}$ Library Review 29, no. 1 (1997): 67-83. doi:10.1006/iilr.1997.0032.

Pritchard, Oliver. "Are You an International University Library?" Library \& Information Update 3, no. 2 (2004): 36-37.

Puente, Mark A., Gray LaVerne, and Shantel Agnew. "The Expanding Library Wall: Outreach to the University of Tennessee's Multicultural/International Student Population." Reference Services Review 37, no. 1 (2009): 30-43. doi:10.1108/00907320910934977.

Qayyum, M. Asim. "Designing an Intercultural Training Framework for Information Professionals." Reference E User Services Quarterly 51, no. 3 (2012): 226-30. doi:10.5860/rusq.51n3.226.

Reznowski, Gabriella. “The Librarian's Role in Motivating Language Learners: Tales from an Eastern Washington College Town." Reference Services Review 36, no. 4 (2008): 414-23. doi:10.1108/00907320810920379.

Robertson, Joan E. “User Education for Overseas Students in Higher Education in Scotland.” Journal of Librarianship and Information Science 24, no. 1 (1992): 33-50. doi:10.1177/096100069202400105.

Sackers, Nicole, Bess Secomb, and Heather Hulett. "How Well Do You Know Your Clients? International Students' Preferences for Learning about Library Services." Australian Academic \& Research Libraries 39, no. 1 (2008): 38-55. doi:10.1080/00048623.2008.10721323.

Sarkodie-Mensah, Kwasi. "Dealing with International Students in a Multicultural Era." The Journal of Academic Librarianship 18, no. 4 (1992): 214-16.

Sarkodie-Mensah, Kwasi. "International Students in the U.S.: Trends, Cultural Adjustments, and Solutions for a Better Experience." Journal of Education for Library and Information Science 39, no. 3 (1998): 214--22. doi:10.2307/40324159.

Saw, Grace, Wendy Abbott, Jessie Donaghey, and Carolyn McDonald. "Social Media for International Students: It's Not All about Facebook." Library Management 34, no. 3 (2013): 156-74. doi:10.1108/01435121311310860.

Schomberg, Jessica, and Barb Bergman. “International Students' Use of a Library's Media Collection." Library Collections, Acquisitions, \& Technical Services 36, no. 3/4 (2012): 121-26. doi:10.1016/j. lcats.2012.08.002.

Schomberg, Jessica, and Michelle Grace. “Expanding a Collection to Reflect Diverse User Populations." Collection Building 24, no. 4 (2005): 124-26. doi:10.1108/01604950510629282.

Shaffer, Christopher, Lisa Vardaman, and Donna Miller. "Library Usage Trends and Needs of International Students." Behavioral \& Social Sciences Librarian 29, no. 2 (2010): 109-17. doi:10.1080/01639261003742231.

Shao, Xiaorong, Allan Scherlen, Megan Johnson, Xuan Xu, and Yuan Hu. "Chinese Students in 
American Academic Libraries: A Survey of Chinese User Satisfaction with US Library Experience." The International Information \& Library Review 45, no. 1/2 (2013): 28-36. doi:10.1016/j. iilr.2013.05.002.

Shao, Xiaorong, and Allan Scherlen. "Chinese Academic Libraries Serving International Students and Scholars: An Assessment of Three Case Studies." The International Information E Library Review 43, no. 1 (2011): 53-61. doi:10.1016/j.iilr.2011.01.003.

Song, Yoo-Seong, and Jong-Moon Lee. "Mobile Device Ownership among International Business Students: A Road to the Ubiquitous Library." Reference Services Review 40, no. 4 (2012): 574-88. doi:10.1108/00907321211277378.

Song, Yoo-Seong. "A Comparative Study on Information-seeking Behaviors of Domestic and International Business Students." Research Strategies 20, no. 1/2 (2004): 23-34. doi:10.1016/j. resstr.2005.07.001.

Song, Yoo-Seong. "International Business Students: A Study on their Use of Electronic Library Services." Reference Services Review 32, no. 4 (2004): 367--73. doi:10.1108/00907320410569716.

Spanfelner, Deborah L. "Teaching Library Skills to International Students." Community E Junior College Libraries 7, no. 2 (1991): 69-76. doi:10.1300/J107v07n02_10.

Tam, Winnie, Andrew M. Cox, and Andy Bussey. "Student User Preferences for Features of Nextgeneration OPACs: A Case Study of University of Sheffield International Students." Program: Electronic Library \& Information Systems 43, no. 4 (2009): 349-74.

Varga-Atkins, Tünde, and Linda Ashcroft. "Information Skills of Undergraduate Business Students - A Comparison of UK and International Students." Library Management 25, no. 1/2 (2004): 39-55. doi:10.1108/01435120410510247.

Wales, Barbara, and Harry Harmon. "A Comparison of Two User Groups: International and U.S. Students in an Academic Library." Public \& Access Services Quarterly 2, no. 4 (1999): 17-37. doi:10.1300/J119v02n04_02.

Wang, Guo-hua. "LLOLI: Language Learning Oriented Library Instruction.” Journal of East Asian Libraries, no. 144 (2008): 16-20. https://ojs.lib.byu.edu/spc/index.php/JEAL/index.

Wang, Jian, and Donald G. Frank. "Cross-Cultural Communication: Implications for Effective Information Services in Academic Libraries." portal: Libraries and the Academy 2, no. 2 (2002): 207-16. doi:10.1353/pla.2002.0046.

Wang, Jiannan. "Toward Understanding International Students: A Study Conducted at Middle Tennessee State University." Southeastern Librarian 56, no. 3 (2008): 4-10. http://digitalcommons.kennesaw.edu/seln/.

Yi, Zhixian. "International Student Perceptions of Information Needs and Use." The Journal of Academic Librarianship 33, no. 6 (2007): 666-73. doi:10.1016/j.acalib.2007.09.003.

Yi, Zhixian. "The Relationship between International Student Library Use and Information Needs." Library and Information Research 37, no. 116 (2013): 23-40. http://www.lirgjournal.org. uk/lir/ojs/index.php/lir/.

Yoon, JungWon, and Soojung Kim. "Internet Use by International Graduate Students in the USA Seeking Health Information." Aslib Journal of Information Management 66, no. 2 (2014): 117-33. doi:10.1108/AJIM-01-2013-0005.

Zhang, Li. "Communication in Academic Libraries: An East Asian Perspective." Reference Services Review 34, no. 1 (2006): 164-76. doi:10.1108/00907320610648842.

Zhang, Wei-Ping. "Foreign Students and U.S. Academic Libraries." College Student Journal 28, no. 4 (1994): 446-51.

Zhang, Weiping. "International Students and U.S. Academic Libraries Revisited." Journal of Library and Information Science (USA/Taiwan) 32, no. 2 (2006): 6-17.

Zhuo, Fu, Jenny Emanuel, and Shuqin Jiao. "International Students and Language Preferences in Library Database Use." Technical Services Quarterly 24, no. 4 (2007): 1-13. doi:10.1300/ J124v24n04_01.

Ziegler, Roy A. "International Students and Country of Origin News." Serials Review 23, no. 1 (1997): 33-46. doi:10.1016/s0098-7913(97)90005-8.

Zimerman, Martin. "Plagiarism and International Students in Academic Libraries." New Library World 113, no. 5/6 (2012): 290-99. doi:10.1108/03074801211226373.

\section{Book Chapters}

Aissing, Alena. "International Education Week: Celebrating the Benefits of International Education and Exchange." In International Students and Academic Libraries: Initiatives for Success. Edited by Pamela A. Jackson and Patrick Sullivan, 83-91. Chicago, Ill.: Association of College \& Research Libraries, 2011.

Amsberry, Dawn, and Loanne Snavely. "Engaging International Students in Academic Library Initiatives for Their Peers." In International Students and Academic Libraries: Initiatives for Success. 
Edited by Pamela A. Jackson and Patrick Sullivan, 69-82. Chicago, Ill.: Association of College \& Research Libraries, 2011.

Badke, William. "Addressing Deeper Issues of Information Literacy in Graduate International Students: A Korean Student Case Study." In International Students and Academic Libraries: Initiatives for Success. Edited by Pamela A. Jackson and Patrick Sullivan, 165-83. Chicago, Ill.: Association of College \& Research Libraries, 2011.

Badke, William. "The Library." In Beyond the Answer Sheet: Academic Success for International Students, 71-86. New York, N.Y.: iUniverse, 2003.

Bahavar, Shahla, Najwa Hanel, Karen Howell, Norah Xiao. "The University of Southern California's Campus-wide Strategies to Reach International Students." In International Students and Academic Libraries: Initiatives for Success. Edited by Pamela A. Jackson and Patrick Sullivan, 213-31. Chicago, Ill.: Association of College \& Research Libraries, 2011.

Bosch, Eileen K., and Valeria E. Molteni. "Connecting to International Students in their Languages: Innovative Bilingual Library Instruction in Academic Libraries." In International Students and Academic Libraries: Initiatives for Success. Edited by Pamela A. Jackson and Patrick Sullivan, 135-50. Chicago, Ill.: Association of College \& Research Libraries, 2011.

Byrne, Alex. "An Integrated Approach to Supporting International Students at the University of Technology, Sydney in Australia." In International Students and Academic Libraries: Initiatives for Success. Edited by Pamela A. Jackson and Patrick Sullivan, 201-11. Chicago, Ill.: Association of College \& Research Libraries, 2011.

DiMartino, Diane, and Lucinda R. Zoe. "International Students and the Library: New Tools, New Users, and New Instruction." In Teaching the New Library to Today's Users. Edited by Trudi E. Jacobson and Helene C. Williams, 17-43. New York, N.Y.: Neal-Schuman, 2000.

Fawley, Nancy. "Addressing Academic Integrity: Perspectives from Virginia Commonwealth University in Qatar." In International Students and Academic Libraries: Initiatives for Success. Edited by Pamela A. Jackson and Patrick Sullivan, 151-64. Chicago, Ill.: Association of College \& Research Libraries, 2011.

Hensley, Merinda Kaye, and Emily Love. "A Multifaceted Model of Outreach and Instruction for International Students." In International Students and Academic Libraries: Initiatives for Success. Edited by Pamela A. Jackson and Patrick Sullivan, 115-34. Chicago, Ill.: Association of College \& Research Libraries, 2011.

Hickok, John. "Knowing Their Background First: Understanding Prior Library Experiences of International Students." In International Students and Academic Libraries: Initiatives for Success. Edited by Pamela A. Jackson and Patrick Sullivan, 1-18. Chicago, Ill.: Association of College \& Research Libraries, 2011.

Hofer, Amy R., and Margot Hanson. "Beyond the One-shot Instruction Session: Semester-long Partnerships for International Student Success." In International Students and Academic Libraries: Initiatives for Success. Edited by Pamela A. Jackson and Patrick Sullivan, 93-113. Chicago, Ill.: Association of College \& Research Libraries, 2011.

Jeong, Sarah H., and David “Giz" Womack. "Connecting@ZSR: Meeting the Research Needs of International Graduate Students." In International Students and Academic Libraries: Initiatives for Success. Edited by Pamela A. Jackson and Patrick Sullivan, 185-99. Chicago, Ill.: Association of College \& Research Libraries, 2011.

Kalin, Sally Wayman. "The International Student in the American Academic Library.” In The Role of the American Library in International Programs. Edited by Bruce D. Bonta and James G. Neal, 147-74. Greenwich, Conn.: JAI Press, 1992.

Law, Elys Kettling, and Nicola Kille. "Creating Research Ambassadors: Expanding the Role of International Students." In International Students and Academic Libraries: Initiatives for Success. Edited by Pamela A. Jackson and Patrick Sullivan, 45-68. Chicago, Ill.: Association of College \& Research Libraries, 2011.

Osa, Justina O. "Teaching International Students to Access and Use Library Resources." In Teaching Information Literacy Skills to Social Sciences Students and Practitioners: A Casebook of Applications. Edited by Douglas Cook and Natasha Cooper, 157--64. Chicago, Ill.: Association of College \& Research Libraries, 2006.

Pastor, Harriet M., and Lisa S. Hemphill. "Acculturation of the International Student in Urban University Libraries." In Academic Libraries in Urban and Metropolitan Areas: A Management Handbook. Edited by Gerald B. McCabe, 215-19. New York, N.Y.: Greenwood Press, 1992.

Peck, Shirley S. "International Students and the Research Process." In Understanding the International Student. Edited by Septimus M. Kaikai and Regina E. Kaikai, 88-101. New York, N.Y.: McGraw-Hill, 1992.

Ruswick, Jannelle. "Engaging International Students before Welcome Week." In International Students and Academic Libraries: Initiatives for Success. Edited by Pamela A. Jackson and Patrick Sullivan, 19-43. Chicago, Ill.: Association of College \& Research Libraries, 2011. 
Sarkodie-Mensah, Kwasi. "The International Student in the U.S. Academic Library." In Diversity and Multiculturalism in Libraries. Edited by Katherine Hoover Hill, 105-20. Greenwich, Conn.: JAI Press, 1994.

Wilson, Vicky. "Library Services for Overseas Students." In Western Perspectives: Library and Information Services in Western Australia. Edited by Robert C. Sharman and Laurel A Clyde, 228-31. Perth, Australia: Australian Library and Information Association (Western Australian Branch), 1990.

\section{Conference Papers}

Burhans, Skip. "Serving the Information Needs of the International and Minority Students at the Small College Library: A Librarian's View." Paper presented at the Annual Meeting of the Central States Communication Association, Chicago, Illinois, April 11-14, 1991.

Hughes, Hilary. "Information Literacy with an International Focus." In International Lifelong Learning Conference: Refereed Papers from the 2nd International Lifelong Learning Conference, Yeppoon, Central Queensland, 16-19 June 2002, Hosted by Central Queensland University. Edited by Ken Appleton, Colin Macpherson, and Debbie Orr, 208-213. Rockhampton, Australia: Central Queensland University Press, 2002.

Hughes, Hilary. "Researching the Experience of International Students." In Lifelong Learning: Whose Responsibility and What Is Your Contribution? Refereed Papers from the 3rd International Lifelong Learning Conference, Yeppoon, Central Queensland, 13-16 June 2004: Hosted by Central Queensland University. Edited by Patrick Alan Danaher, Colin Macpherson, Fons Nouwens, and Debbie Orr, 168-74. Rockhampton, Australia: Central Queensland University Press, 2004.

Hughes, Hilary. "The International-Friendly Library: Customising Library Services for Students from Overseas." Paper presented at the Australian Library and Information Association's (ALIA) 2001 Technical and Further Education (TAFE) Libraries Conference, Brisbane, Australia, October 22-23, 2001. http://conferences.alia.org.au/tafe2001/papers/hilary.hughes.html.

Kirkpatrick, Denise and Diana Trezise. "Research Skills for Students for Whom English Is a Second Language." In Conference Proceedings: Papers Presented at the Australian Library and Information Association 1st Biennial Conference: Perth, W.A. September 30-October 5, 1990 (vol. 2), 637-44. Applecross, Australia: Promaco Conventions, 1990.

Mehra, Bharat, and Dania Bilal. "International Students' Perceptions of Their Information Seeking Strategies." In Proceedings of the Annual Conference of the Canadian Association of Information Science, Montreal, Quebec, 10-12 May 2007. Edited by Clément Arsenault and Kimiz Dalkir. http://www.cais-acsi.ca/ojs/index.php/cais/issue/archive.

Onwuegbuzie, Anthony J., Qun G. Jiao, and Christine E. Daley. “The Experience of Non-Native English-Speaking Students in Academic Libraries in the United States." Paper presented at the Annual Conference of the Mid-South Educational Research Association, Memphis, Tenn., November 12-14, 1997. http://eric.ed.gov/?id=ED438815.

Wallin, Margie, Debbie Orr, and Jillian Litster. "Information Literacy: Assessing the Needs of International Students at Central Queensland University." In Proceedings of the Third Pacific Rim Conference on the First Year in Higher Education, Auckland, NZ, 5-8 July 1998. Edited by Roger Stokell. Auckland, New Zealand: Auckland Institute of Technology, 1998.

Wilson, Vicky, and Edith Lauk. "Independent Learning Skills and the Overseas Student: The Role of the Library." In Conference Proceedings: Papers Presented at the Australian Library and Information Association 1st Biennial Conference: Perth, W.A., September 30-October 5, 1990 (vol. 2), 657-79. Applecross, Australia: Promaco Conventions, 1990. 


\section{Appendix B. All Journals Represented in the Study}

\begin{tabular}{|c|c|}
\hline Journal Title & $\begin{array}{c}\text { Number of } \\
\text { Articles }\end{array}$ \\
\hline 1. Reference Services Review & 13 \\
\hline 2. The Journal of Academic Librarianship & 11 \\
\hline 3. The Reference Librarian & 10 \\
\hline 4. The International Information \& Library Review & 6 \\
\hline 5. College \& Research Libraries & 5 \\
\hline 6. $\quad$ Research Strategies & 5 \\
\hline 7. Australian Academic \& Research Libraries & 3 \\
\hline 8. Library Philosophy \& Practice & 3 \\
\hline 9. Canadian Journal of Information \& Library Sciences & 2 \\
\hline 10. College \& Undergraduate Libraries & 2 \\
\hline 11. Journal of East Asian Libraries & 2 \\
\hline 12. Journal of Information Literacy & 2 \\
\hline 13. Library \& Information Research & 2 \\
\hline 14. Library Management & 2 \\
\hline 15. New Library World & 2 \\
\hline 16. Science \& Technology Libraries & 2 \\
\hline 17. Southeastern Librarian & 2 \\
\hline 18. Technical Services Quarterly & 2 \\
\hline 19. The Australian Library Journal & 2 \\
\hline 20. Academic Exchange & 1 \\
\hline 21. ALISS Quarterly & 1 \\
\hline 22. Aslib Journal of Information Management & 1 \\
\hline 23. Behavioral \& Social Sciences Librarian & 1 \\
\hline 24. Bulletin (Special Libraries Association. Geography \& Map Division) & 1 \\
\hline 25. CALA Occasional Paper Series & 1 \\
\hline 26. Collaborative Librarianship & 1 \\
\hline 27. Collection Building & 1 \\
\hline 28. College Student Journal & 1 \\
\hline 29. Community \& Junior College Libraries & 1 \\
\hline 30. Education Libraries & 1 \\
\hline 31. Electronic Library & 1 \\
\hline 32. Georgia Librarian & 1 \\
\hline 33. Information Outlook & 1 \\
\hline 34. Information Research & 1 \\
\hline 35. International Journal of Learning & 1 \\
\hline
\end{tabular}




\begin{tabular}{|c|c|}
\hline Journal Title & $\begin{array}{c}\text { Number of } \\
\text { Articles }\end{array}$ \\
\hline 36. Journal of Education for Library and Information Science & 1 \\
\hline 37. Journal of Educational Media and Library Sciences & 1 \\
\hline 38. Journal of Electronic Resources Librarianship & 1 \\
\hline 39. Journal of Further and Higher Education & 1 \\
\hline 40. Journal of Librarianship and Information Science & 1 \\
\hline 41. Journal of Library Administration & 1 \\
\hline 42. Journal of Library and Information Science (USA/Taiwan) & 1 \\
\hline 43. Kentucky Libraries & 1 \\
\hline 44. Law Library Journal & 1 \\
\hline 45. Library \& Information Update & 1 \\
\hline 46. Library Collections, Acquisitions, \& Technical Services & 1 \\
\hline 47. Library Review & 1 \\
\hline 48. Multicultural Review & 1 \\
\hline 49. PNLA Quarterly & 1 \\
\hline 50. portal: Libraries \& the Academy & 1 \\
\hline 51. Program: Electronic Library \& Information Systems & 1 \\
\hline 52. Public and Access Services Quarterly & 1 \\
\hline 53. Public Services Quarterly & 1 \\
\hline 54. Reference \& User Services Quarterly & 1 \\
\hline 55. Serials Review & 1 \\
\hline 56. Teaching English in the Two $\square$ Year College & 1 \\
\hline 57. The Reading Matrix: An International Online Journal & 1 \\
\hline 58. Urban Library Journal & 1 \\
\hline \begin{tabular}{|l} 
TOTAL \\
\end{tabular} & 117 \\
\hline
\end{tabular}




\section{Appendix C. Annotated Bibliographies Not Included in the Study}

Davis, Kaetrena D. Global Evolution: A Chronological Annotated Bibliography of International Students in U.S. Academic Libraries. Chicago, Ill.: Association of College \& Research Libraries, 2007.

Peters, Diane E. International Students and Academic Libraries: A Survey of Issues and Annotated Bibliography. Lanham, Md.: Scarecrow Press, 2010.

Moeckel, Nancy, and Jenny Presnell. "A Companion Bibliography to: Recognizing, Understanding, and Responding: A Program Model of Library Instruction Services for International Students." The Reference Librarian 24, no. 51/52 (1995): 327-53. doi:10.1300/j120v24n51_30.

\section{Notes}

1. Institute of International Education, Open Doors 2014: A 15-Year Snapshot (2014), available online at http://iie.org/Research-and-Publications/Open-Doors [accessed 1 June 2015].

2. Mark Petticrew and Helen Roberts, Systematic Reviews in the Social Sciences: A Practical Guide (Malden, Mass.; Oxford, United Kingdom: Blackwell Publishing, 2006), 11, doi:10.1002/9780470754887.

3. Diane Kelly and Cassidy R. Sugimoto, "A Systematic Review of Interactive Information Retrieval Evaluation Studies, 1967-2006," Journal of the American Society for Information Science and Technology 64, no. 4 (2013): 745-70, doi:10.1002/asi.22799.

4. Denise Koufogiannakis, "The State of Systematic Reviews in Library and Information Studies," Evidence Based Library and Information Practice 7, no. 2 (2012): 91-95, available online at https://ejournals.library.ualberta.ca/index.php/EBLIP/article/view/17089 [accessed 1 June 2015].

5. Cynthia Thomes, "Keeping Up With...Systematic Literature Reviews," 2016, available online at http://www.ala.org/acrl/publications/keeping_up_with/slr [accessed 1 June 2015].

6. Karen Bordonaro, Internationalization and the North American University Library (Lanham, Md.: Scarecrow Press), 1.

7. Jane Knight, Internationalisation: Elements and Checkpoints (Ottawa, Canada: Canadian Bureau for International Education), 7.

8. Jane Knight, "Internationalization Remodeled: Definition, Approaches, and Rationales," Journal of Studies in International Education 8, no. 1 (2004): 11, doi:10.1177/1028315303260832.

9. Philip G. Altbach and Jane Knight, "The Internationalization of Higher Education: Motivations and Realities," Journal of Studies in International Education 11, no. 3/4 (2007): 290-305, doi:10.1177/1028315307303542.

10. American Council on Education, Educating Americans for a World in Flux: Ten Ground Rules for Internationalizing Higher Education (Washington, D.C.: American Council on Education, 1995$), 1$.

11. NASULGC Task Force on International Education, A Call to Leadership: The Presidential Role in Internationalizing the University, 2004, available online at https://archive.org/details/ERIC_ED483871 [accessed 1 June 2015].

12. Committee for Economic Development, Education for Global Leadership: The Importance of International Studies and Foreign Language Education for U.S. Economic and National Security (Washington, D.C.: Committee for Economic Development, 2006), available online at http://files.eric. ed.gov/fulltext/ED502294.pdf [accessed 1 June 2015].

13. American Council on Education, Mapping Internationalization on U.S. Campuses: 2012 Edition (Washington, D.C.: American Council on Education, 2012), available online at https://www. acenet.edu/news-room/Documents/Mapping-Internationalizationon-US-Campuses-2012-full.pdf [accessed 1 June 2015].

14. Steven W. Witt, Laurie Kutner, and Liz Cooper, "Mapping Academic Library Contributions to Campus Internationalization," College E Research Libraries 76, no. 5 (2015): 604, doi:10.5860/ crl.76.5.587.

15. Bordonaro, Internationalization and the North American University Library, 43-47.

16. Zhonghong Wang and Paul Tremblay, "The Global Library: Providing Resources and Services to International Sites," College E Undergraduate Libraries 16, no. 1 (2009): 26-52, doi:10.1080/10691310902754239.

17. Kayo Denda, "Study Abroad Programs: A Golden Opportunity for Academic Library Engagement," Journal of Academic Librarianship 39, no. 2 (2013): 155-60, doi:10.1016/j.acalib.2012.08.008.

18. Laurie Kutner, "Think Locally, Act Globally: Understanding Home Institution Library Engagement among Study-Abroad Students," College E Research Libraries 70, no. 2 (2009): 158-76, doi:10.5860/crl.70.2.158. 
19. Ismail Abdullahi, Leif Kajberg, and Sirje Virkus, "Internationalization of LIS Education in Europe and North America," New Library World 108, no. 1/2 (2007): 7-24, doi:10.1108/03074800710722144.

20. Leif Kajberg, "A Survey of Internationalisation Activities in European Library and Information Science Schools," Journal of Studies in International Education 8, no. 4 (2004): 352-76, doi:1 0.1080/13614550410001687918.

21. See Jill Barr-Walker, "Start-Up Library: My Experience at NYU Abu Dhabi," College $\mathcal{E}$ Undergraduate Libraries 20, no. 2 (2013): 224-31, doi:10.1080/10691316.2013.789691; Beth Clausen, "Think Globally, Act Locally: A Library Perspective," portal: Libraries and the Academy 15, no. 3 (2015): 389-92, doi:10.1353/pla.2015.0031.

22. Harriett Green, "Libraries across Land and Sea: Academic Library Services on International Branch Campuses," College \& Research Libraries 74, no. 1 (2011): 9-23, doi:10.5860/crl-259.

23. Amanda B. Click and Meggan Houlihan, "Library Instruction Programs at American-Style Academic Libraries outside of the United States," in Bridging Worlds: Emerging Models and Practices of U.S. Academic Libraries around the Globe, eds. Raymond Pun, Scott Collard, and Justin Parrott (Chicago, Ill.: Association of College \& Research Libraries, forthcoming).

24. Petticrew and Roberts, Systematic Reviews in the Social Sciences, 9.

25. Kelly and Sugimoto, "A Systematic Review of Interactive Information Retrieval Evaluation Studies," 749.

26. Koufogiannakis, "The State of Systematic Reviews in Library and Information Studies."

27. Denise Koufogiannakis, LIS Systematic Reviews, available online at http://lis-systematicreviews.wikispaces.com/ [accessed 1 June 2015].

28. Petticrew and Roberts, Systematic Reviews in the Social Sciences, 21.

29. Kelly and Sugimoto, "A Systematic Review of Interactive Information Retrieval Evaluation Studies," 750-54.

30. International Students and Academic Libraries: Initiatives for Success, eds. Pamela A. Jackson and Patrick Sullivan (Chicago, Ill.: Association of College \& Research Libraries, 2011).

31. Nancy Moeckel and Jenny Presnell, "Recognizing, Understanding, and Responding: A Program Model of Library Instruction Services for International Students," Reference Librarian 24, no. 51/52 (1995): 309-25, doi:10.1300/J120v24n51_29.

32. See Yoo-Seong Song and Jong-Moon Lee, "Mobile Device Ownership among International Business Students: A Road to the Ubiquitous Library," Reference Services Review 40, no. 4 (2012): 574-88, doi:10.1108/00907321211277378; JungWon Yoon and Soojung Kim, "Internet Use by International Graduate Students in the USA Seeking Health Information," Aslib Journal of Information Management 66, no. 2 (2014): 117-33, doi:10.1108/ajim-01-2013-0005.

33. See Yusuke Ishimura and Joan C. Bartlett, "Are Librarians Equipped to Teach International Students? A Survey of Current Practices and Recommendations for Training," Journal of Academic Librarianship 40, no. 3 (2014): 313-21, doi:10.1016/j.acalib.2014.04.009.

34. See Xiaorong Shao et al., "Chinese Students in American Academic Libraries: A Survey of Chinese User Satisfaction with US Library Experience," International Information \& Library Review 45, no. 1 (2013): 28-36, doi:10.1016/j.iilr.2013.05.002.

35. Iljong Park, "A Comparative Study of Major OPACs in Selected Academic Libraries for Developing Countries - User Study and Subjective User Evaluation," International Information $\mathcal{E}$ Library Review 29, no. 1 (1997): 67-83, doi:10.1006/iilr.1997.0032.

36. Philip C. Howze and Dorothy M. Moore, “Measuring International Students' Understanding of Concepts Related to the Use of Library-Based Technology," Research Strategies 19, no. 1 (2003): 57-74, doi:10.1016/s0734-3310(03)00005-3.

37. Yu-Hui Chen and Mary K. Van Ullen, "Helping International Students Succeed Academically through Research Process and Plagiarism Workshops," College \& Research Libraries 72, no. 3 (2011): 209-35, doi:10.5860/crl-117rl.

38. Karen Bordonaro, "Exploring the Connections between Information Literacy and Writing for International Students," Journal of Information Literacy 2, no. 2 (2008): 1-17, doi:10.11645/2.2.67.

39. See Yusuke Ishimura, Vivian Howard, and Haidar Moukdad, "Information Literacy in Academic Libraries: Assessment of Japanese Students' Needs for Successful Assignment Completion in Two Halifax Universities," Canadian Journal of Information and Library Science 31, no. 1 (2007): 1-26; Ligaya Ganster, "Reaching Out to International Students: A Focus-Group Approach to Developing Web Resources and Services," College \& Undergraduate Libraries 18, no. 4 (2011): 368-84, doi:10.1080/10691316.2011.624933.

40. See Guoying Liu and Danielle Winn, "Chinese Graduate Students and the Canadian Academic Library: A User Study at the University of Windsor," Journal of Academic Librarianship 35, no. 6 (2009): 565-73, doi:10.1016/j.acalib.2009.08.001; Karen Bordonaro, "Is Library Database Searching a Language Learning Activity?" College \& Research Libraries 71, no. 3 (2010): 273-84, doi:10.5860/0710273. 
41. Lorrie Knight, Maryann Hight, and Lisa Polfer, "Rethinking the Library for the International Student Community," Reference Services Review 38, no. 4 (2010): 581-605, doi:10.1108/00907321011090746.

42. Yusuke Ishimura and Joan C. Bartlett, "Uncovering the Research Process of International Students in North America: Are They Different from Domestic Students?" Information Research 18, no. 1 (2013), available online at www.informationr.net/ir/ [accessed 1 June 2015].

43. Charity K. Martin et al., "Closing the Gap: Investigating the Search Skills of International and US Students: An Exploratory Study," Library Philosophy \& Practice (2009), available online at http://digitalcommons.unl.edu/libphilprac/ [accessed 1 June 2015].

44. Jessica Schomberg and Barb Bergman, "International Students' Use of a Library's Media Collection," Library Collections, Acquisitions, \& Technical Services 36, no. 3/4 (2012): 121-26, doi:10.1016/j.lcats.2012.08.002.

45. Jinghe Han, "The Experiences of Chinese PhD Students in Australia: Encountering Information Literacy Challenges," Journal of Information Literacy 6, no. 1 (2012): 3-17, doi:10.11645/6.1.1603.

46. Ann Curry and Deborah Copeman, "Reference Service to International Students: A Field Stimulation Research Study," Journal of Academic Librarianship 31, no. 5 (2005): 409-20, doi:10.1016/j. acalib.2005.05.011.

47. Miriam Conteh-Morgan, "Connecting the Dots: Limited English Proficiency, Second Language Learning Theories, and Information Literacy Instruction," Journal of Academic Librarianship 28, no. 4 (2002): 191-96, doi:10.1016/s0099-1333(02)00282-3.

48. Karen Bordonaro, "Language Learning in the Library: An Exploratory Study of ESL Students," Journal of Academic Librarianship 32, no. 5 (2006): 518-26, doi:10.1016/j.acalib.2006.06.009.

49. Schomberg and Bergman, "International Students' Use of a Library's Media Collection."

50. Sei-Ching Joanna Sin and Kyung-Sun Kim, "International Students' Everyday Life Information Seeking: The Informational Value of Social Networking Sites," Library \& Information Science Research 35, no. 2 (2013): 107-16, doi:10.1016/j.lisr.2012.11.006.

51. Yusuke Ishimura, "Information Behavior and Japanese Students: How Can an Understanding of the Research Process Lead to Better Information Literacy?" Public Services Quarterly 9, no. 1 (2013): 20-33, doi:10.1080/15228959.2013.758977.

52. Han, "The Experiences of Chinese PhD Students in Australia"; Hilary Hughes, "International Students Using Online Information Resources to Learn: Complex Experience and Learning Needs," Journal of Further and Higher Education 37, no. 1 (2013): 126-46; doi:10.1080/030987 7X.2011.644778.

53. Tina Hurley, Nora Hegarty, and Jennifer Bolger, "Crossing a Bridge: The Challenges of Developing and Delivering a Pilot Information Literacy Course for International Students," New Library World 107, no. 7/8 (2006): 302-20, doi:10.1108/03074800610677281.

54. Ishimura and Bartlett, "Are Librarians Equipped to Teach International Students?"

55. See Ishimura, "Information Behavior and Japanese Students."

56. See Liu and Winn, "Chinese Graduate Students and the Canadian Academic Library"; Yao Chen and Cecelia Brown, "Ensuring Chinese Engineering Graduate Students' Academic Success: A Study at the University of Oklahoma," Science \& Technology Libraries 31, no. 3 (2012): 320-41, doi:10.1080/0194262x.2012.705144.

57. Yoon and Kim, "Internet Use by International Graduate Students in the USA Seeking Health Information."

58. Drew DeSilver, "Growth from Asia Drives Surge in U.S. Foreign Students," Pew Research Center Fact Tank (June 18, 2015), available online at www.pewresearch.org/fact-tank/2015/06/18/ growth-from-asia-drives-surge-in-u-s-foreign-students/ [accessed 1 June 2015]; Malcolm Gillies, Australia's Drive for International Students," Times Higher Education (March 14, 2013), available online at https://www.timeshighereducation.com/comment/columnists/australias-drive-forinternational-students/2002507.article [accessed 1 June 2015].

59. Jessica Schomberg and Michelle Grace, "Expanding a Collection to Reflect Diverse User Populations," Collection Building 24, no. 4 (2005): 124-26, doi:10.1108/01604950510629282.

60. Mark A. Puente, Gray LaVerne, and Shantel Agnew, "The Expanding Library Wall: Outreach to the University of Tennessee's Multicultural/International Student Population," Reference Services Review 37, no. 1 (2009): 30-43, doi:0.1108/00907320910934977.

61. See Renée Morrissey and Lisa M. Given, "International Students and the Academic Library: A Case Study," Canadian Journal of Information E Library Sciences 30, no. 3/4 (2006): 221-39; Liu and Winn, "Chinese Graduate Students and the Canadian Academic Library"; Shao et al., "Chinese Students in American Academic Libraries."

62. See Pamela A. Jackson, "Incoming International Students and the Library: A Survey," Reference Services Review 33, no. 2 (2005): 197-209, doi:10.1108/00907320510597408; Ilka Datig, "What Is a Library? International College Students' Perceptions of Libraries," Journal of Academic Librarianship 40, no. 3 (2014): 350-56, doi:10.1016/j.acalib.2014.05.001. 
63. See Jian Wang and Donald G. Frank, "Cross-Cultural Communication: Implications for Effective Information Services in Academic Libraries," portal: Libraries and the Academy 2, no. 2 (2002): 207-16, doi:10.1353/pla.2002.0046; Fu Zhuo, Jenny Emanuel, and Shuqin Jiao, "International Students and Language Preferences in Library Database Use," Technical Services Quarterly 24, no. 4 (2007): 1-13, doi:10.1300/j124v24n04_01.

64. See Conteh-Morgan, "Connecting the Dots"; Bordonaro, "Language Learning in the Library."

65. See Grace Saw et al., "Social Media for International Students - It's Not All about Facebook," Library Management 34, no. 3 (2013): 156-74, doi:10.1108/01435121311310860; Sin and Kim, "International Students' Everyday Life Information Seeking."

66. See Yoo-Seong Song, "A Comparative Study on Information-Seeking Behaviors of Domestic and International Business Students," Research Strategies 20, no. 1 (2004): 23-34, doi:10.1016/j. resstr.2005.07.001; Zhixian Yi, "International Student Perceptions of Information Needs and Use," Journal of Academic Librarianship 33, no. 6 (2007): 666-73, doi:10.1016/j.acalib.2007.09.003.

67. Ishimura, Howard, and Moukdad, "Information Literacy in Academic Libraries."

68. Hilary Hughes, "Actions and Reactions: Exploring International Students' Use of Online Information Resources," Australian Academic \& Research Libraries 36, no. 4 (2005): 169-79, doi:10. 1080/00048623.2005.10755308; Martin et al., "Closing the Gap."

69. Mirna E. Turcios, Naresh Kumar Agarwal, and Linda Watkins, "How Much of Library and Information Science Literature Qualifies as Research?" Journal of Academic Librarianship 40, no. 5 (2014): 473-79, doi:10.1016/j.acalib.2014.06.003.

70. Megan Oakleaf, The Value of Academic Libraries (Chicago, Ill.: Association of College and Research Libraries, 2010), available online at www.ala.org/acrl/sites/ala.org.acrl/files/content/ issues/value/val_report.pdf [accessed 1 June 2015].

71. Sally Wayman Kalin, "The International Student in the American Academic Library," in The Role of the American Library in International Programs, eds. Bruce D. Bonta and James G. Neal (Greenwich, Conn.: JAI Press, 1992), 147-74.

72. Mary Beth Allen, "International Students in Academic Libraries: A User Survey," College $\mathcal{E}$ Research Libraries 54, no. 4 (1993): 323-33, doi:10.5860/crl_54_04_323.

73. Ziming Liu, "Difficulties and Characteristics of Students from Developing Countries in Using American Libraries," College E Research Libraries 54, no. 1 (1993): 25-31, doi:10.5860/ crl_54_01_25.

74. Sara Baron and Alexia C. Strout-Dapaz, "Communicating with and Empowering International Students with a Library Skills Set," Reference Services Review 29, no. 4: 314-26, doi:10.1108/00907320110408447.

75. Jackson, "Incoming International Students and the Library: A Survey."

76. Curry and Copeman. "Reference Service to International Students."

77. Yan Liao, Mary Finn, and Jun Lu, "Information-Seeking Behavior of International Graduate Students vs. American Graduate Students: A User Study at Virginia Tech 2005," College E Research Libraries 68, no. 1 (2007): 5-25, doi:10.5860/crl.68.1.5.

78. Petticrew and Roberts, Systematic Reviews in the Social Sciences, 21.

79. Petticrew and Roberts, Systematic Reviews in the Social Sciences, 11. 